\title{
The cryo-EM structure of the neurofibromin dimer reveals the molecular basis for von Recklinghausen disease.
}

\author{
Christopher J. Lupton ${ }^{1,8}$, Charles Bayly-Jones ${ }^{1,2,8}$, Laura D'Andrea ${ }^{1,8}$, Cheng Huang ${ }^{3}$, Ralf B. Schittenhelm ${ }^{3}$, \\ Hari Venugopal ${ }^{4}$, James C. Whisstock ${ }^{1,2,5,6}$, Michelle L. Halls ${ }^{7}$, Andrew M. Ellisdon ${ }^{1 凶}$ \\ ${ }^{1}$ Biomedicine Discovery Institute, Monash University, Clayton 3800, Victoria, Australia \\ ${ }^{2}$ ARC Centre of Excellence in Advanced Molecular Imaging, Monash University, Clayton 3800, Victoria, Australia \\ ${ }^{3}$ Monash Proteomics \& Metabolomics Facility, Monash University, Clayton 3800, Victoria, Australia \\ ${ }^{4}$ Ramaciotti Centre for Cryo-Electron Microscopy, Monash University, Clayton 3800, Victoria, Australia \\ ${ }^{5}$ EMBL Australia, Monash University, Melbourne, 3800, Victoria, Australia. ${ }^{6}$ ACRF Department of Cancer Biology and Therapeutics, \\ John Curtin School of Medical Research, Australian National University, Canberra 2601, ACT, Australia. ${ }^{7}$ Drug Discovery Biology Theme, \\ Monash Institute of Pharmaceutical Sciences, Monash University, Parkville 3052, Victoria, Australia \\ ${ }^{8}$ These authors contributed equally. \\ Correspondence: andrew.ellisdon@monash.edu ${ }^{凶}$
}

Neurofibromin (NF1) is a tumour suppressor mutated in neurofibromatosis type 1 (von Recklinghausen disease), one of the most common human genetic diseases(1). NF1 regulates cellular growth through suppressing the Rat Sarcoma (RAS) pathway and, accordingly, mutations in this protein drive numerous cancers, including melanoma, ovarian, breast and brain cancer( 2,3$)$. Currently, however, the molecular basis for NF1 function remains to be understood. Here we address this problem and use cryogenic Electron Microscopy (cryo-EM) to determine the structure of fulllength NF1. The $640 \mathrm{kDa}$ NF1 homodimer forms an extraordinary lemniscate $(\infty)$ shaped molecule that is $\sim 30 \mathrm{~nm}$ in length and $\sim 10 \mathrm{~nm}$ wide. Each NF1 monomer comprises an N-terminal HEAT-repeat domain (N-HEAT), a guanosine triphosphatase activating protein (GAP)-related domain (GRD), a Sec14 homologous and pleckstrin homologous module (SEC-PH), and a C-terminal HEAT domain (C-HEAT). The core NF1 scaffold is formed via a head-to-tail dimer of the $\mathrm{N}$ - and C-HEAT domains. This platform, which is responsible for interacting with more than 10 regulatory binding partners, comprises an extraordinary array of over $150 \alpha$-helices. Analysis of these EM data revealed that the GRD and SEC-PH domain are highly mobile with respect to the core scaffold and could not initially be accurately placed in electron density. Strikingly, however, using 3D variability analysis we were able to identify a significant subpopulation of NF1 particles and determine the complete NF1 structure to $5.6 \AA$ resolution. These data revealed that the catalytic GRD and lipid binding SEC-PH domain are positioned against the core scaffold in a closed, autoinhibited conformation. We postulate that interaction with the plasma membrane may release the closed conformation in order to promote RAS inactivation. Our structural data further allow us to map the location of disease-associated NF1 variants and provide a long sought-after structural explanation for the extreme susceptibility of the molecule to loss-of-function mutations. Finally, it is suggested that approaches to combat NF1-linked diseases may include release of the autoinhibited state in order to improve NF1 catalytic efficiency.

Neurofibromin | von Recklinghausen disease | cancer | neurofibromatosis | cryoEM | autoinhibition | RAS | SPRED1 | tumor suppressor

The oncogenic RAS family of small GTP-binding proteins (Neuroblastoma RAS, Harvey RAS, and Kirsten RAS) have crucial roles in coordinating eukaryotic cell growth(4). Growth factor signalling promotes the cycling of RAS proteins from their inactive GDP-bound state to their active GTP-bound state. GTP-bound RAS proteins activate fundamental signalling pathways such as the RAF-MEK-ERK cascade and the PI3K-Akt-mTOR pathway(5). NF1 is a highly conserved RAS GAP that catalyses the hydrolysis of RAS-bound GTP(6). As such, NF1 acts as a potent off-switch for RAS-family signalling(2) (Extended Data Fig. $1)$.

Germline and sporadic mutations of NF1 cause the common genetic condition neurofibromatosis type 1 (von Recklinghausen disease) with variable clinical presentations, including benign cutaneous and plexiform neurofibromas1. NF1 is also a common driver gene in numerous cancers(7) with frequent mutations, deletions, or structural rearrangements in melanoma(8), breast cancer(9), lung cancer(10), and glioblastoma(11). Mutations that cause neurofibromatosis type 1 and cancer-associated somatic mutations are distributed throughout the NFl gene(12, 13) without widespread clustering to the catalytic GAP domain, suggesting an acute susceptibility of the entire protein to dysregulation. NF1 inactivation increases GTP-bound RAS levels driving downstream activation of MAPK and PI3K pathways and aberrant cell growth(14-16). NF1 loss further dysregulates many additional processes that lead to cognitive defects(17), conferral of drug resistance in cancer therapy(18), and learning defects(19).

NF1 interacts with a very large number of cellular binding proteins and effectors (Extended Data Fig. 1). Notably, NF1 binds Sprouty Related EVH1 Domain Containing 1 (SPRED1), an event that enables its membrane recruitment(20). The SEC-PH module is also postulated to play an additional role in membrane recruitment through lipid and phosphoinositide (PI) binding(21). Once at the membrane the catalytic NF1 GRD stabilises GTP-bound 
a

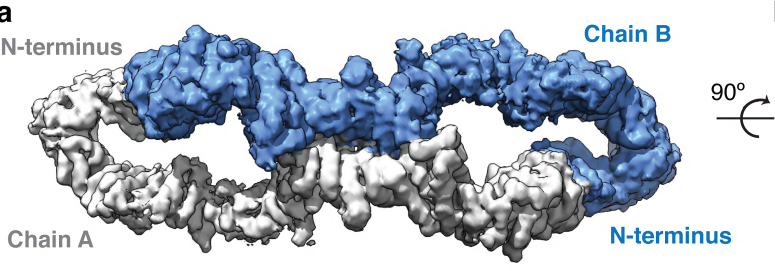

C

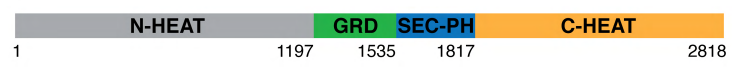

b

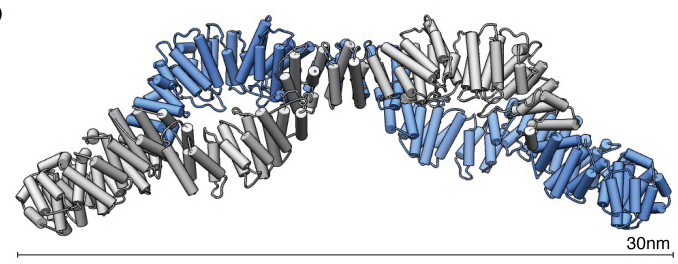

e

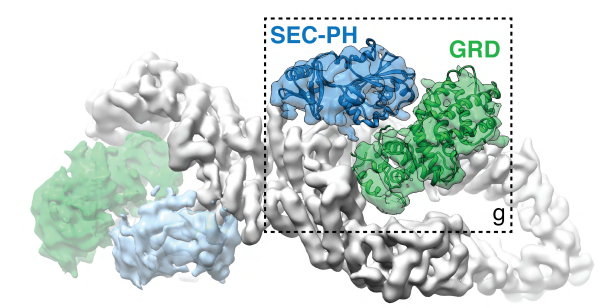

g: SEC-PH

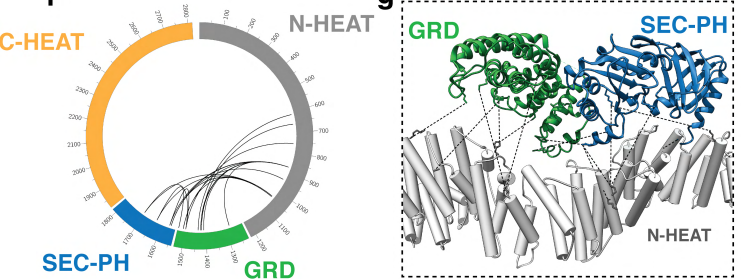

SEC-PH

GRD

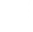

Fig. 1. Structure of the NF1 homodimer. a. The 4.6 A cryo-EM (composite) map of the NF1 core highlighting the intercalation of each monomer chain to form an extended lemniscate dimer. b. Overview of the NF1 dimer structure with $\alpha$-helices as cylinders. c. Schematic of the NF1 domain layout. d. Overview of the domain organisation of the complete NF1 dimer structure with $\alpha$-helices as cylinders. Overall, the N-HEAT domain forms a helicoidal arrangement of $\alpha$-helices marked by the formation of a tight arch at each tip of the molecule. The N-terminal arch allows the N-HEAT domain to extend back towards the centre of the molecule. The GRD exits the central fold and runs back out along the edge of the N-HEAT domain before doubling back to form the SEC-PH module and re-joining the C-HEAT domain. The C-HEAT $\alpha$-helical domain forms a central symmetrical dimer interface with the equivalent C-HEAT domain of the second dimer chain. The fold is closed at each end by two symmetrically equivalent interfaces that link the N- and C-termini of each dimer chain. e. The $5.6 \AA$ cryo-EM map of the autoinhibited NF1 dimer oriented to display the fits of the atomic models of the GRD20 and SEC-PH21 domains. f. Intradomain $\mathrm{BS}^{3}$ and $\mathrm{BS}^{2} \mathrm{G}$ crosslinks detected between the N-HEAT, GRD, and SEC-PH domains ( $\mathrm{n}=3$ ). $\mathbf{g}$. Boxed region from e shown to highlight the compatibility of crosslinks with the conformation of the GRD and SEC-PH domains.

RAS to promote GTP-hydrolysis(22, 23). SEC-PH binding to G-protein $\beta \gamma$ can also inhibit NF1, modulating RAS activation and neural pathways central to opioid addiction(24). Multiple further binding sites are distributed throughout NF1 including sites for tubulin binding in mitosis(25), 14-3-3 binding(26), as well as protein kinase $\mathrm{A}$ and $\mathrm{C}$ phospho-regulation(27).

To better understand NF1 function we expressed recombinant protein in insect cells and determined the cryo-EM structure of the full-length $640 \mathrm{kDa}$ homodimer. The structure presented significant challenges with respect to particle heterogeneity, however, after symmetry expansion one wing of the NF1 homodimer could be reconstructed to a nominal resolution of $4.6 \AA$ (Fig 1a, Extended Movie 1, Extended Data Fig. 2, 3, 4 and Extended Data Table 1). The maps were of sufficient quality to completely build and sequence de novo the N- and C-HEAT domains (Fig. 1b and Extended Data Fig. 5). In contrast, however, the central GRD and SEC-PH domains were poorly resolved and showed a high degree of mobility within the majority of particles. To address this, we used $3 \mathrm{D}$ variability analysis to identify a subpopulation of NF1 particles and determined the $5.6 \AA$ structure of the complete NF1 molecule (Extended Data Fig. 4). In this latter reconstruction, clear secondary structure density was observed for the entire molecule (Fig. 1c-e) and crystal structures of both the GRD(20) and SEC-PH modules(21) could be fitted unequivocally into the density with each domain packed against the $\mathrm{N}$ - and C-HEAT domains. Extensive crosslinking mass spectrometry with $\mathrm{BS}^{3}$ and $\mathrm{BS}^{2} \mathrm{G}$ lysine crosslinkers confirm the placement of the central GRD and SEC-PH domains into the cryo-EM maps (Fig. 1f, g) as well as the sequence assignment of the dimeric N- and C-HEAT repeat core (Extended Data Fig. 5 and Extended Data Table 2). The GRD also crosslinks to known phospho-regulatory regions in NF1 (Extended Data Fig. 6).

Analysis of these structural data reveal that the NF1 scaffold comprises a large lemniscate-shaped assembly that forms as a consequence of head-to-tail dimerization of the $\mathrm{N}$ - and C-HEAT domains (Fig. 1a and Extended Movie 1). Each wing of the structure curves away from a central interface with an outer dimension spanning a remarkable $\sim 30 \mathrm{~nm}$ between each tip (Fig. 1b). Despite being well resolved in the cryo-EM maps, the central scaffold is remarkably flexible with a large degree of continuous conformational heterogeneity detected across the dataset (Extended Movie 2). Docking sites of more than 10 known NF1 binding partners map across the entire NF1 structure (Extended Data Fig. 7). These data suggest, that like the karyopherin HEAT-repeat family(28), the core scaffold acts as a flexible interaction platform coordinating the many functions of NF1 that span from cell growth(2) to cell division(25). 
a

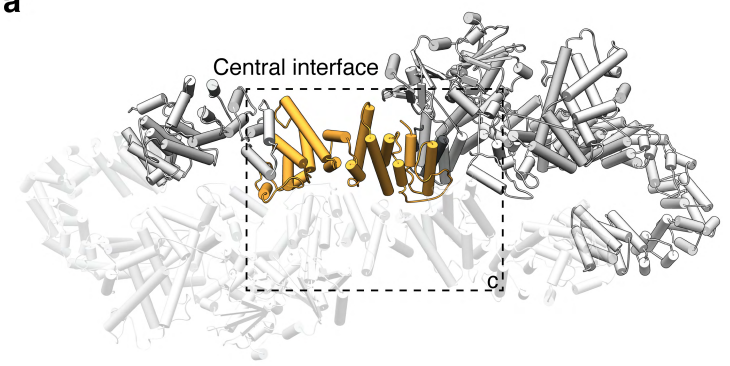

b

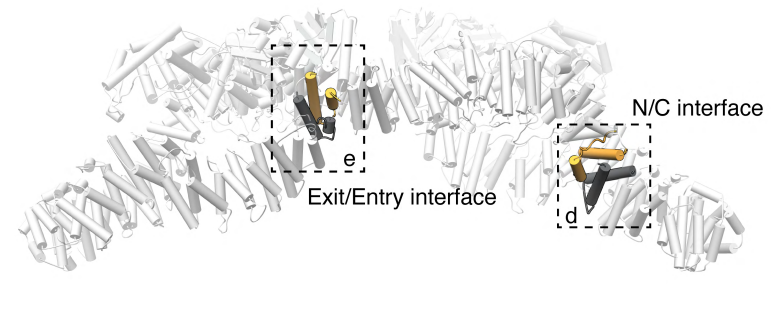

C

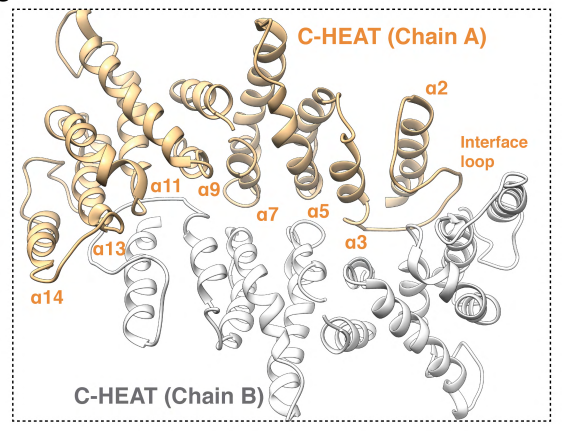

d

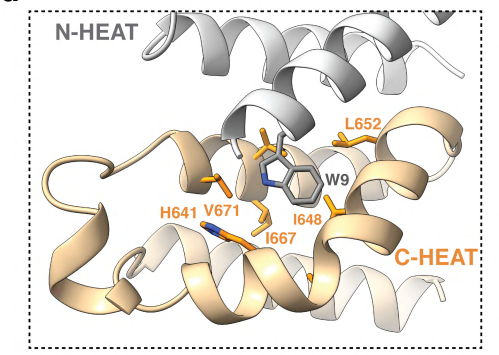

e

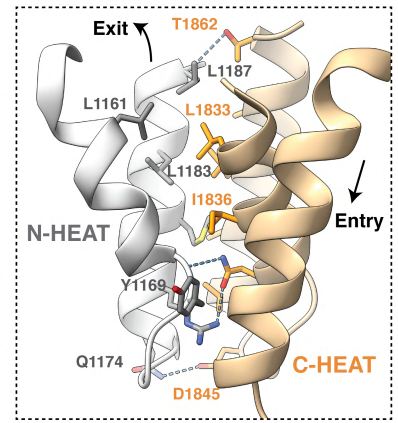

Fig. 2. Structural basis of NF1 dimer assembly. a. The NF1 structure with the symmetrical central interface formed between the two C-HEAT domains highlighted. b. The NF1 structure with a single N/C interface and Exit/Entry interface highlighted. c. Boxed region from a with key interacting secondary structure elements indicated. d. Boxed region from $b$ highlighting the W9 residue of the N-HEAT domain buried in the hydrophobic pocket of the C-HEAT domain. e. Boxed region of $b$ highlighting key interacting residues in the continuous HEAT-repeat array interface of the $\mathrm{N}$ - and C-HEAT domains. Arrows indicate the direction of the exit and entry $\alpha$-helices that support the placement of the GRD and SEC-PH domains on the core scaffold. Select amino acids are shown as sticks and indicated by single letter code. Potential hydrogen-bonds displayed as blue dotted lines.

NF1 dimer assembly is mediated by five interfaces. The central interface formed by the symmetrical and anti-parallel alignment of the C-HEAT domains, two symmetrically equivalent $\mathrm{N}$ - and $\mathrm{C}$-terminal interfaces that close each end of the lemniscate HEAT-repeat fold, and two entry and exit interfaces that enable the flexible GRD and SEC-PH domains to align on the edge of the core scaffold (Fig. 2a, b). The central interface is extensive ( $\sim 1670 \AA^{2}$ buried surface area) and formed by multiple C-HEAT domain helices as well as the highly conserved $\alpha \mathrm{C} 2-3$ loop that is sandwiched at each end of the symmetrical interface (Fig. 2a, c). The central interface is particularly well conserved and likely the main energetic driver of NF1 dimer assembly (Extended Data Fig. 8 and Extended Data Fig. 9).

The two smaller ( $~ 905 \AA^{2}$ buried surface area) equivalent $\mathrm{N}$ - and $\mathrm{C}$-HEAT interfaces are formed by the packing of helices $\alpha \mathrm{N} 1$ and $\alpha \mathrm{N} 2$ of the N-HEAT domain with helices $\alpha \mathrm{C} 32$ and $\alpha \mathrm{C} 33$ of the $\mathrm{C}$-HEAT domain to form a continuous helicoid topology (Fig. 2d). The centre of the interface is predominantly hydrophobic, with the conserved N-HEAT tryptophan (W9) deeply buried into a hydrophobic pocket formed by helices $\alpha \mathrm{C} 32$ and $\alpha \mathrm{C} 33$ (Fig. 2d). The two entry and exit interfaces are formed by the N-HEAT helical pair $\alpha \mathrm{N} 44$ and $\alpha \mathrm{N} 45$ that form a continuous HEAT-repeat like array with the C-HEAT helical pair $\alpha \mathrm{C} 1$ and $\alpha \mathrm{C} 2$. A total of $\sim 850 \AA^{2}$ is buried in each interface with predominantly hydrophobic packing between helices (Fig. 2e). This interface is central to supporting the integrity of the central scaffold as well as the flexible positioning of the GRD and SEC-PH domains on the scaffold edge.

In the $5.7 \AA$ structure of the complete NF1 molecule, the GRD and SEC-PH modules pack tightly against the $\mathrm{N}$ and C-HEAT domains. Whilst resolution limited detailed analysis, the GRD sits buried in the cleft formed by the $\mathrm{N}$ and C-HEAT domains making contacts with both conserved C-HEAT domain $\alpha$-helices as well as surface loops of the N-HEAT repeats (Fig. 3a-c). Analysis of the closed NF1 structure reveals that the RAS-binding interface is oriented towards the central scaffold in a conformation that is sterically incompatible with direct RAS binding (Fig. $3 \mathrm{a}, \mathrm{b})$. Similarly, the lipid binding sites of both the SEC and PH domains(21) are also occluded and would need to undertake significant rotation to enable membrane binding (Fig. 3d, e). In contrast, the modelled SPRED1 binds intimately to NF1 surface potentially interfacing with a previously unrecognized site in the C-HEAT domain (Fig. $3 \mathrm{~b}, \mathrm{c})$ providing a clear route for SPRED1-driven membrane recruitment(29).

Collectively these data suggest that we have identified a closed conformation of NF1. Our data further suggest that significant rearrangement of both the GRD and SEC-PH domains must take place upon SPRED1 membrane recruitment in order to enable RAS turnover and lipid binding, respectively (Fig. 3e). Consistent with this idea, our structural data reveal that GRD and SEC-PH domains are highly mobile and can thus readily transition between the closed 
bioRxiv preprint doi: https://doi.org/10.1101/2021.02.18.431788; this version posted February 18, 2021. The copyright holder for this preprint (which was not certified by peer review) is the author/funder, who has granted bioRxiv a license to display the preprint in perpetuity. It is made available under aCC-BY 4.0 International license.

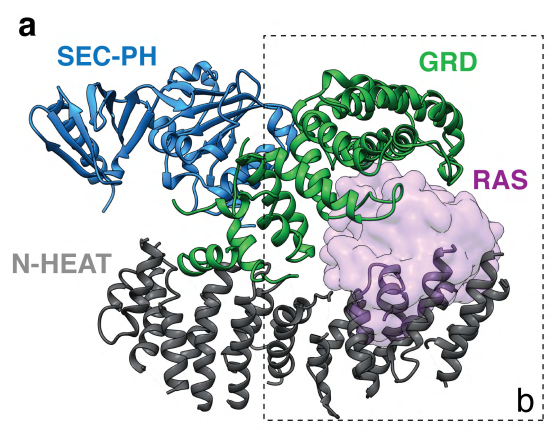

d

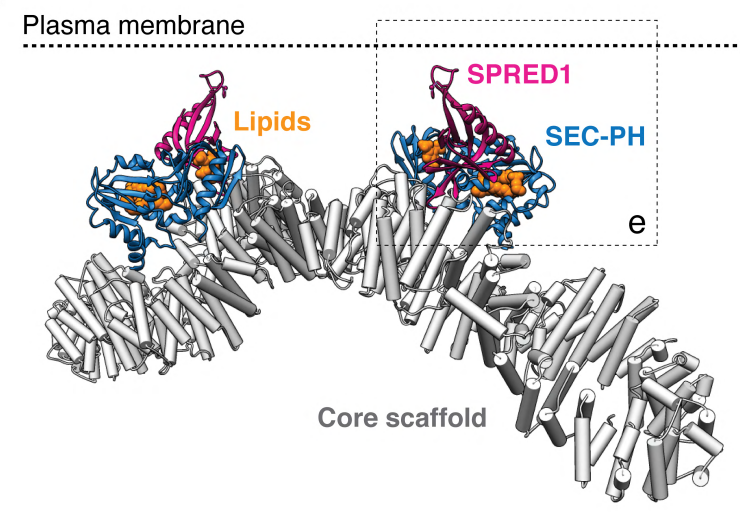

$\mathbf{f}$

OSPRED1 interface
ORAS interface
OLipid sites

b

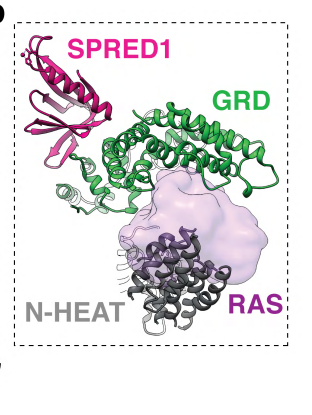

C

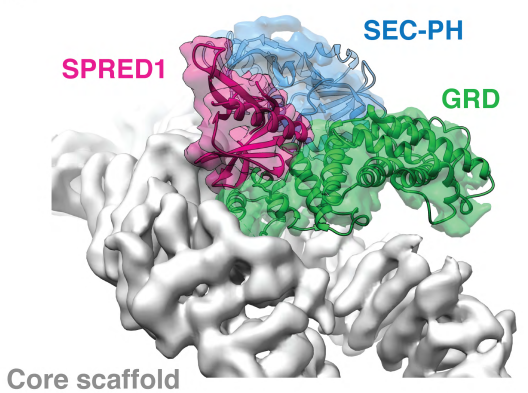

e
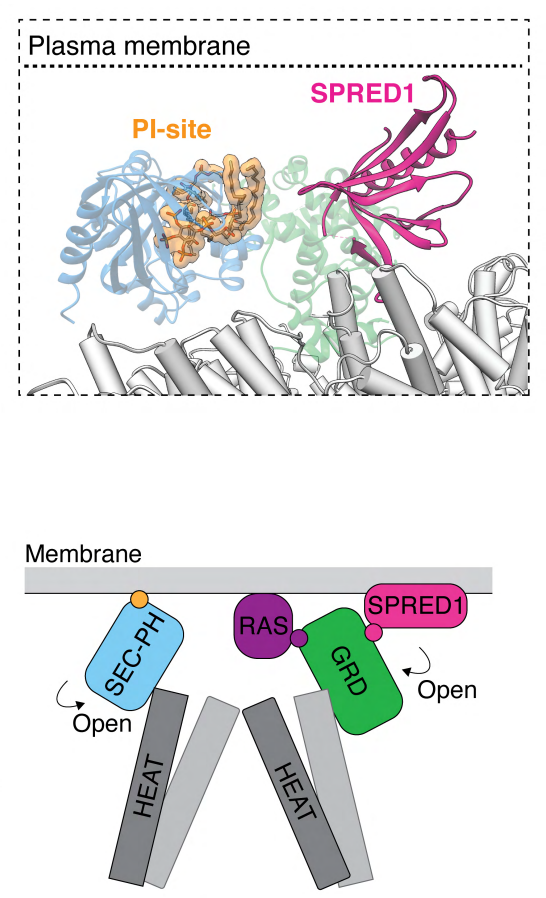

Open NF1

Fig. 3. The GRD and SEC-PH domains are in a closed conformation. a. RAS binding to the GRD is sterically occluded by the N-HEAT domain. b. Boxed region from a rotated to highlight steric clashes of RAS with the N-HEAT domain and the SPRED1 binding site exposed on the GRD domain. c. NF1 oriented to highlight the close association of the modelled SPRED1 domain to the central scaffold. d. The NF1 structure oriented to highlight the horizontal alignment of the SEC-PH lipid binding pockets as well as the SPRED1 binding region on each GRD. The predicted plasma membrane position is indicated to highlight the symmetrical alignment of known NF1 membrane binding regions. e. Boxed region from d highlighting the buried PI binding site in the PH domain. f. Proposed regulatory model of NF1. A subpopulation of NF1 is in a stable closed conformation marked by the steric occlusion of the GRD interface and lipid-binding sites. The SPRED1 binding site(20) is exposed on the surface of the closed GRD conformation and is known to recruit NF1 to the membrane(29). Conformational rearrangements of the GRD and SEC-PH modules are required for RAS and lipid binding, respectively. For clarity, the model displays only a GRD or SEC-PH domain on each side of the core scaffold.

conformation and an open conformation where the GRD and SEC-PH domains are exposed and flexible.

Lastly, in order to gain understanding of the molecular basis of neurofibromatosis type 1 we analysed the frequency of disease-associated mutations across the $N F 1$ gene $(13,30)$ (Fig. 4a.). Neurofibromatosis type 1 mutations are evenly spread throughout the gene with only sporadic clustering evident along its length. Analysis of the COSMIC(12) database also highlights that somatic cancer-associated mutations are evenly distributed throughout the NFl gene (Fig. 4b). We mapped these disease-associated mutations onto the NF1 structure to gain greater insight into the mechanistic basis of loss-of-function of this key tumour suppressor protein (Fig. $4 \mathrm{c}$ ). For example, the clinically significant neurofibromatosis type 1 mutants $(\Delta \mathrm{M} 991(31))$ and $(\Delta$ L844-G848(32)) map to the N-HEAT domain and would likely interfere with helical packing directly beneath the SEC-PH interface (Fig. 4d). In addition, the common cancer-associated mutation $\mathrm{R} 1849 \mathrm{Q}$ (33) packs intricately against the central interface ( $\alpha$ C2-3) loop, a crucial region for NF1 dimer assembly (Fig. $4 \mathrm{e})$. However, globally, NF1 mutations do not cluster to any one interface or region of the protein but are uniformly distributed throughout the structure (Fig. 4c). It is clear from the intricate NF1 fold that missense, deletion, or nonsense mutations are likely to have an acute effect on the stability of the entire NF1 protein fold. For example, any mutation that disrupts the intricate HEAT-repeat packing of the core scaffold may result in an inability of the lemniscate-fold to close and downstream loss of function. 
This sensitivity of the NF1 fold to mutations also rationalises the lack of mutational hot spots within the tumour suppressor.
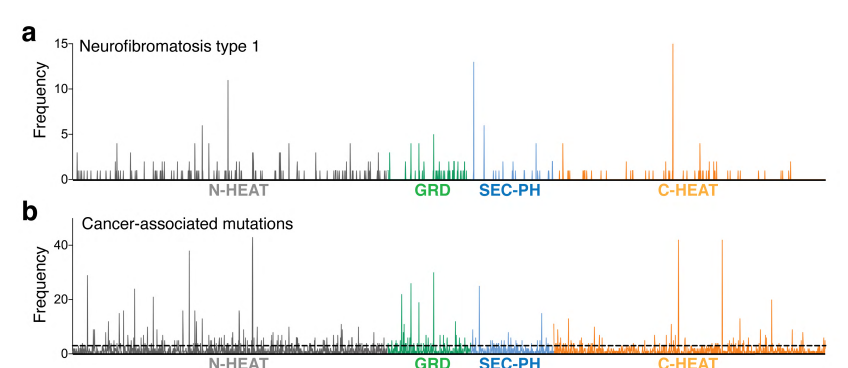

c

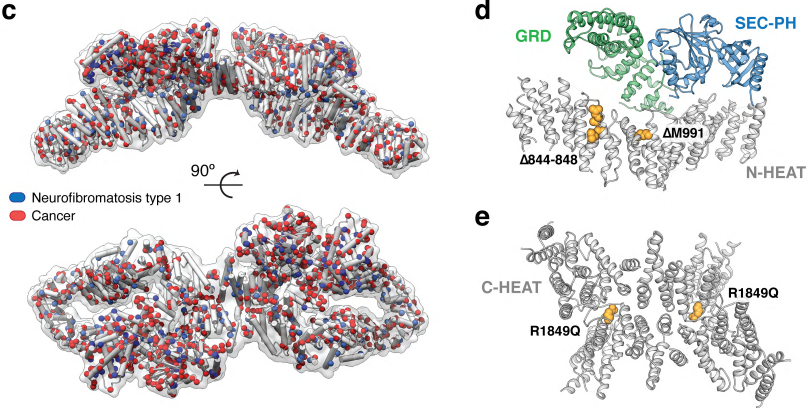

Fig. 4. Distribution of neurofibromatosis type 1 and cancer-associated NF1 mutations. a. Frequency of neurofibromatosis type 1 (von Recklinghausen disease) mutations from two patient studies $(13,30)$. b. Frequency of NF1 cancerassociated mutations found in the COSMIC(12) database mapped across the NF1 gene. Sites of missense, nonsense, and deletions are included in the analysis to highlight the lack of clustering. Positioning of the NF1 domains from the cryo-EM structure are indicated $\mathbf{c}$. The NF1 structure with $\mathrm{C} \alpha$ atoms of residues mutated in neurofibromatosis type 1 (blue) or cancer (red) displayed as spheres. All neurofibromatosis type 1 mutations from the indicated studies are displayed and for clarity cancer-associated mutations are only displayed if they were in the COSMIC12 database three or more times. d. Indicate neurofibromatosis type 1 mutants are within the N-HEAT domain close to the GRD interface. e. Location of the cancerassociated R1849Q mutant within the central NF1 dimer interface.

In conclusion, we have shown that NF1 assembles into a large homodimer characterised by a central lemniscateshaped core formed by the assembly of the $\mathrm{N}$ - and C-HEAT domains. NF1 dimer assembly requires the coordinated packing of eight domains, which contain over $150 \alpha$-helices, to form the final topology. This highly mobile molecular scaffold provides an elongated binding platform for both the GRD and SEC-PH domains as well as the many NF1 cellular effector molecules that have been identified to date. We have further identified a sub-population of NF1 with the catalytic and lipid binding domains in a closed conformation suggesting a previously unidentified mechanism of NF1 autoinhibition. This pivotal role of the core scaffold in coordinating both NF1 activity and regulation provides a rationale for the evolutionary conservation of this unusually complex fold.

Finally, our work provides a long-sought after molecular and structural context for NF1 dysregulation in disease. As such, mutation or deletion at a disproportionate number of sites is likely to cause mis-assembly of the dimer and acute loss-of-function. We propose that the complex nature of the NF1 fold is thus a major contributing factor for the acute sensitivity of the NF1 gene to mutations in disease. However, given the identification of the closed conformation of NF1 we hypothesise that developing molecules to stabilize the open conformation may represent a strategy to rescue NF1 loss-of-function in disease where an active allele remains.

\section{Material and methods}

\section{Protein expression and purification.}

NF1 (isoform 1) was subcloned from R777-E139 Hs.NF1 (a gift from Dominic Esposito, Addgene plasmid \#70423) as an $\mathrm{N}$-terminal $\mathrm{His}_{6}$-tagged protein in pFastBac1 (Invitrogen). NF1 was expressed in Sf9 cells for 2 days following baculovirus infection (Bac-to-Bac, Invitrogen). Cells were harvested by centrifugation and lysed by sonication in 20 $\mathrm{mm}$ Tris-HCl pH 8.0, $500 \mathrm{~mm} \mathrm{NaCl}, 10 \%$ (v/v) glycerol, and $5 \mathrm{~mm} \beta$-mercaptoethanol. Lysates were cleared by centrifugation, filtered at $0.45 \mu \mathrm{m}$, and incubated with Ni-NTA resin (Qiagen) and $20 \mathrm{~mm}$ imidazole at $4{ }^{\circ} \mathrm{C}$ with agitation. The resin was washed with lysis buffer, and NF1 eluted with $500 \mathrm{~mm}$ imidazole in the same buffer. NF1-containing fractions were further purified on a Superose 6 10/300 GL size-exclusion column (Cytiva) equilibrated in $20 \mathrm{~mm}$ HEPES pH 8.0, $150 \mathrm{~mm} \mathrm{NaCl}$, and $2 \mathrm{~mm}$ DTT.

Site-directed mutagenesis was performed on KRAS 1-169 (Q61H, isoform b, a gift from Cheryl Arrowsmith, Addgene plasmid \#25153) to obtain the wild-type sequence. N-terminally His6-tagged KRAS was expressed in BL21CodonPlus(DE3)-RIL cells (Stratagene) by isopropyl- $\beta$-D-1thiogalactopyranoside induction at $18^{\circ} \mathrm{C}$. Cells were lysed by sonication in $20 \mathrm{~mm}$ Tris- $\mathrm{HCl} \mathrm{pH} 8.0,500 \mathrm{~mm} \mathrm{NaCl}, 10 \%$ $(\mathrm{v} / \mathrm{v})$ glycerol, and $3 \mathrm{mM} \beta$-mercaptoethanol, with two complete EDTA-free protease inhibitor tablets (Roche). Cells were clarified by centrifugation, filtered through a $0.45 \mu \mathrm{m}$ membrane, and incubated with Ni-NTA resin (Qiagen) and $20 \mathrm{~mm}$ imidazole at $4{ }^{\circ} \mathrm{C}$ with agitation. The resin was washed with lysis buffer and KRAS was eluted in lysis buffer containing $300 \mathrm{~mm}$ imidazole. KRAS-containing fractions were further purified on a HiLoad Superdex 75 16/60 (Cytiva) pre-equilibrated with $20 \mathrm{mM}$ HEPES $\mathrm{pH} 8.0,150 \mathrm{mM}$ $\mathrm{NaCl}, 10 \%$ (v/v) glycerol, and $2 \mathrm{~mm}$ DTT.

\section{Cryo-EM sample preparation and data collection.}

Quantifoil R1.2/1.3 200 mesh copper grids were glow discharged for $90 \mathrm{~s}$ at $15 \mathrm{~mA}$ using a Pelco easiGlow instrument. Freshly purified NF1 $\left(3 \mu \mathrm{L}\right.$ at $0.5 \mathrm{mg} \mathrm{m}^{-1}$ ) was applied to the freshly discharged grid and vitrified in liquid ethane using a Vitrobot Mk IV (Thermo Fisher Scientific) with a blot of force of -2 for $2.5 \mathrm{~s}$. Temperature and relative humidity were maintained at $4{ }^{\circ} \mathrm{C}$ and $100 \%$, respectively. Data were collected on a Talos Arctica (Thermo Scientific) operating at $200 \mathrm{kV}$ with a $50 \mu \mathrm{m} \mathrm{C} 2$ aperture. Micrographs were acquired using a bottom mounted Falcon 3 direct electron detector in counting mode at a nominal magnification of $120,000 \times$, corresponding to a calibrated physical pixel size of $1.194 \AA$. The electron dose rate was set to 0.8 electrons 
pixel $^{-1} \mathrm{~s}^{-1}$ with a total exposure time of $71.68 \mathrm{~s}$, yielding a total dose of 40 electrons $\AA^{-2}$. Automated collection was carried out using EPU with beam-shift to collect 9 images per stage movement. Defocus range was set between -0.5 to $-2.2 \mu \mathrm{m}$.

\section{Cryo-EM data processing.}

All initial data monitoring and micrograph denoising were performed in Warp(34) (v1.0.9) to assess grid quality and select appropriate regions for data collection. An initial pass of the data was performed in cryoSPARC(35) (v2.14.2). Here, particle picking was performed by the elliptical blob method, these 23,480 particles were extracted in a box of 432 pixels, down sampled to $2.388 \AA \mathrm{Ap}^{\mathrm{p} x \mathrm{xel}^{-1}}$ and subjected to $2 \mathrm{D}$ classification. An ab initio model was generated from 1,818 particles without imposing symmetry.

Upon completion of data collection, 2,675 dose-fractionated movies were corrected for beam induced motion and compensated for radiation damage within MotionCor2(36) (v1.1.0). All aligned movie frames were subsequently summed into dose-weighted averages for further processing. The contrast transfer function parameters were re-estimated with CTFFIND(37) (v4.1.8). Curated particles from the initial pass were used to train a crYOLO(38) (v1.6.1) model which was used to pick 192,225 particles from the full dataset. These were subjected to multiple rounds of $2 \mathrm{D}$ classification in both RELION(39) (v3.1) and cryoSPARC, yielding 95,564 particles of sufficient quality and homogeneity. A consensus reconstruction was generated by refining this subset in RELION with C2 symmetry yielding an $8.2 \AA$ map after polishing and re-sampling to $1.194 \AA$ pixel $^{-1}$. These particles were 3D classified in RELION without further alignments. A single subset was refined using RELION and SIDESPLITTER(40) yielding a map of $7.5 \AA$ resolution. Further local refinement in cryoSPARC lead to a final dimer reconstruction at $6.2 \AA$ resolution.

CryoSPARC 3D variational analysis and RELION multibody analysis was performed on the consensus reconstruction to assess the degree of flexibility and guide signal subtraction. These analyses revealed significant movement of the two NF1 wings, as well as flexibility within individual lobes. Therefore, symmetry expansion of the consensus reconstruction was performed, and each wing was re-extracted after signal subtraction of the other wing. This gave rise to 191,128 sub-particles in a 256-pixel box. An additional round of 2D classification was performed to remove empty and junk particles. Refinement in RELION yielded a 6.4 $\AA$ map after symmetry expansion and signal subtraction, indicating flexibility of the NF1 homodimer had significantly limited the resolution of the consensus reconstruction. Further 3D classification of these particles yielded two homogenous subsets. Refinement of the CTF parameters was performed in cisTEM(41) with a high-resolution cut-off maintained above the fall-off of the FSC. Lastly, a final homogenous refinement was performed with RELION and SIDESPLITTER yielding a $4.56 \AA$ resolution map. Con- versions between software were performed with EMAN(42) (v2.2), with code written in-house or by pyem. The FSC was used to estimate resolution at the 0.143 threshold. Local resolution was estimated by the windowed blocres FSC method as implemented in cryoSPARC. Map sharpening was performed in RELION, an ad hoc B-factor of $-80 \AA^{-2}$ was selected by inspection of the map.

A second round of 3D variation analysis was performed on the symmetry expanded particles, which after 3D principal component analysis, revealed a small discrete cluster of particles corresponding to an autoinhibited state of NF1. This subpopulation of 9,283 particles was re-extracted at the original pixel size and locally refined with gaussian priors to prevent diverging from previous alignment parameters. This analysis resulted in a $5.6 \AA$ resolution map of the autoinhibited NF1 with GRD and SEC-PH domains with clearly resolved secondary structure.

The model of the N-HEAT and C-HEAT domains was built manually into the cryo-EM map using $\operatorname{Coot}(43)$, with iterative cycles of refinement carried out using PHENIX(44) and Isolde(45). Secondary structure and adaptive network constraints were employed until the final round of refinement, where only secondary structure constraints were imposed. The structure had excellent final geometry (Extended Data Table 1). Structures of both the GRD(20) (PDB: 6V65) and SEC-PH(21) (PDB: 3PG7) domains were rigid body fit into the $5.7 \AA$ cryo-EM reconstruction with excellent agreement between the EM and crystal structures to produce an autoinhibited NF1 model. A final, full NF1 dimer model was generated by rigid body fitting the autoinhibited NF1 model into the $6.2 \AA$ dimer reconstruction.

\section{CLMS.}

Crosslinking mass spectrometry was performed by adding either $\mathrm{BS}^{3}$ (Thermo Fisher) or $\mathrm{BS}^{2} \mathrm{G}$ (Thermo Fisher) crosslinkers at a 1:100 molar ratio to $4 \mu \mathrm{M} N F 1$ in $20 \mathrm{mM}$ HEPES pH 8.5, $150 \mathrm{~mm} \mathrm{NaCl}$, and $2 \mathrm{~mm}$ DTT. For $\mathrm{BS}^{3}$, samples were incubated at room temperature for $20 \mathrm{~min}$ prior to the addition of $50 \mathrm{~mm}$ Tris- $\mathrm{HCl} \mathrm{pH} 8.0$ to quench the reaction. For $\mathrm{BS}^{2} \mathrm{G}$, samples were incubated at room temperature for $30 \mathrm{~min}$ prior to the addition of $20 \mathrm{mM}$ $\mathrm{NH}_{4} \mathrm{HCO}_{3}$ to quench the reaction. For both crosslinkers, samples were snap-frozen in liquid nitrogen prior to further processing. Samples were subsequently denatured for 30 min at $65{ }^{\circ} \mathrm{C}$ in the presence of $10 \mathrm{~mm}$ DTT. Subsequently, $40 \mathrm{mM}$ chloroacetamide was then added to the samples prior to incubation for $20 \mathrm{~min}$ at room temperature in the dark. A $1: 100(\mathrm{w} / \mathrm{w})$ ratio of trypsin was added to the samples and further incubated at $37^{\circ} \mathrm{C}$ overnight. Digestion was stopped with the addition of $1 \%(\mathrm{v} / \mathrm{v})$ formic acid. Samples were subsequently cleaned using OMIX C18 pipette tips (Agilent Technologies) and stored in $0.1 \%(\mathrm{v} / \mathrm{v})$ formic acid prior to mass spectrometry.

Samples were analysed by LC-MS/MS using a Dionex Ultimate 3000 RSLCnano system coupled onto an Orbi- 
bioRxiv preprint doi: https://doi.org/10.1101/2021.02.18.431788; this version posted February 18, 2021. The copyright holder for this preprint (which was not certified by peer review) is the author/funder, who has granted bioRxiv a license to display the preprint in perpetuity. It is made available under aCC-BY 4.0 International license.

trap Fusion Tribrid instrument (Thermo Fisher). An Acclaim PepMap RSLC analytical column $(75 \mu \mathrm{m} \times 50 \mathrm{~cm}$, nanoViper, C18, $2 \mu \mathrm{m}, 100 \AA$ A; Thermo Scientific) and an Acclaim PepMap 100 trap column $(100 \mu \mathrm{m} \times 2 \mathrm{~cm}$, nanoViper, $\mathrm{C} 18,5 \mu \mathrm{m}, 100 \AA$ А Thermo Scientific) were used to separate tryptic peptides by increasing concentrations of $80 \%(\mathrm{v} / \mathrm{v})$ acetonitrile (can) / $0.1 \%(\mathrm{v} / \mathrm{v})$ formic acid at a flow of 250 $\mathrm{nl} \min ^{-1}$ for $90 \mathrm{~min}$. The mass spectrometer was operated in data-dependent mode with the following parameters. The cycle time was controlled for $3 \mathrm{~s}$. The MS1 resolution was set at 120,000 and scan range of $375-2000 \mathrm{~m} / \mathrm{z}$. The AGC target was set at $1.0 \times 10^{6}$ with an injection time of $118 \mathrm{~ms}$. The MS2 resolution was set at 60,000 and the AGC target was set at $4.0 \times 10^{5}$ with an injection time of $118 \mathrm{~ms}$. pLink and pLink2 were used to identify $\mathrm{BS}^{3}$ - or $\mathrm{BS}^{2} \mathrm{G}$-crosslinked peptides(46). Each CLMS dataset is derived from three repeats and crosslinked peptides were analysed if they were identified at least twice with a $P$ value of less than $10^{-4}$ and were greater than 10 residues apart. Visual representations of crosslinked peptides were generated in $\operatorname{Circos}(47)$.

GAP-activity assays. Assays for GAP-stimulated GTP hydrolysis were performed using the GTPase-Glo kit (Promega) based on the protocol by Mondal et al(48). Briefly, KRAS (wild-type) was added to white opaque 384-well plates (Corning) at a final concentration of $0.5 \mu \mathrm{M}$ and GTPase reactions were initiated by adding NF1 at a final concentration of $0.5 \mu \mathrm{M}$ (final volume $40 \mu \mathrm{L}$ with $5 \mu \mathrm{M}$ GTP added to buffer). Samples were incubated for $90 \mathrm{~min}$ at room temperature and luminescence measured using a BMG CLARIOstar plate reader with emission at $545-550 \mathrm{~nm}$. In each case, we performed three independent experiments in duplicate. Data are expressed as the mean \pm standard error of the mean.

\section{Sedimentation velocity analytical ultracentrifugation.}

Sedimentation velocity analytical ultracentrifugation experiments were performed with full-length NF1 at $1 \mu \mathrm{M}$ in $20 \mathrm{mM}$ HEPES pH 8.0, $150 \mathrm{mM} \mathrm{NaCl}$ and $1 \mathrm{mM}$ DTT on a Beckman Coulter Optima analytical ultracentrifuge with An60Ti rotor at $25,000 \mathrm{rpm}$ at $21{ }^{\circ} \mathrm{C}$. Absorbance data was collected at $280 \mathrm{~nm}$, and all data and frictional ratio calculations were analysed in SEDFIT(49). Buffer density, buffer viscosity and sample partial specific volumes were calculated based on their composition in SEDNTERP.

\section{DATA AVAILABILITY}

The three-dimensional cryo-EM density maps are deposited into the Electron Microscopy Data Bank (https://www.ebi.ac.uk/pdbe/emdb/) under accession number XXX. The coordinates are deposited in the Protein Data Bank (https://www.rcsb.org) with accession number XXX. Mass spectrometry proteomics data have been deposited to the ProteomeXchange Consortium via the PRIDE(50) partner repository with the dataset identifier PXD023593.

\section{ACKNOWLEDGEMENTS}

M.L.H. is a Viertel Senior Medical Research Fellow supported by The Cross Family and The Frank Alexander Charitable Trusts. J.C.W. is an Australian Research Council Laureate Fellow and honorary National Health and Medical Research Council of Australia Senior Principal Research Fellow. This research was supported by a NHMRC Project Grant to M.L.H. (APP1121029) and equipment funded by an Australian Research Council Grant (LE170100016). CBJ acknowledges the support of the Australian Government by way of an RTP stipend. The authors acknowledge the use of instruments and assistance at the Monash Ramaciotti Centre for Cryo-Electron Microscopy, a Node of Microscopy Australia. We also acknowledge the office of the Vice-Provost for Research and Research Infrastructure (VPRRI) at
Monash University and of Bioplatforms Australia (BPA) as part of the National Collaborative Research Infrastructure Strategy (NCRIS). This preprint was formatted in ${ }^{L} T_{E} X$ using an adaptation of Ricardo Henriques' template.

\section{AUTHOR CONTRIBUTIONS}

A.M.E. and M.L.H. conceived the study. C.J.L. and L.D. performed cloning, protein expression, and purification. C.J.L. prepared cryo-EM grids. C.J.L. and H.V. collected cryo-EM data. C.B-J., C.J.L. and A.M.E. processed cryo-EM data, built, and refined atomic models. C.J.L. and L.D. performed GAP activity assays. L.D., C.H. and R.B.S. performed crosslinking and mass spectrometry. All authors contributed to analyses of data and writing of the manuscript.

\section{Bibliography}

1. D. H. Gutmann, R. E. Ferner, R. H. Listernick, B. R. Korf, P. L. Wolters, and K. J. Johnson. Neurofibromatosis type 1. Nat Rev Dis Primers, 3:17004, 2017. ISSN 2056-676X (Electronic) 2056-676X (Linking). doi: 10.1038/nrdp.2017.4.

2. N. Ratner and S. J. Miller. A rasopathy gene commonly mutated in cancer: the neurofibromatosis type 1 tumour suppressor. Nat Rev Cancer, 15(5):290-301, 2015. ISSN 1474-1768 (Electronic) 1474-175X (Linking). doi: 10.1038/nrc3911.

3. G. F. Xu, P. O'Connell, D. Viskochil, R. Cawthon, M. Robertson, M. Culver, D. Dunn, J. Stevens, R. Gesteland, R. White, and et al. The neurofibromatosis type 1 gene encodes a protein related to gap. Cell, 62(3):599-608, 1990. ISSN 0092-8674 (Print) 0092-8674 (Linking). doi: 10.1016/0092-8674(90)90024-9.

4. S. Li, A. Balmain, and C. M. Counter. A model for ras mutation patterns in cancers: finding the sweet spot. Nat Rev Cancer, 18(12):767-777, 2018. ISSN 1474-1768 (Electronic) 1474-175X (Linking). doi: 10.1038/s41568-018-0076-6.

5. R. J. Shaw and L. C. Cantley. Ras, pi(3)k and mtor signalling controls tumour cell growth. Nature, 441(7092):424-30, 2006. ISSN 1476-4687 (Electronic) 0028-0836 (Linking). doi: 10.1038 /nature04869.

6. K. Cichowski and T. Jacks. Nf1 tumor suppressor gene function: narrowing the gap. Cell, 104(4):593-604, 2001. ISSN 0092-8674 (Print) 0092-8674 (Linking). doi: 10.1016/ s0092-8674(01)00245-8.

7. Icgc Tcga Pan-Cancer Analysis of Whole Genomes Consortium. Pan-cancer analysis of whole genomes. Nature, 578(7793):82-93, 2020. ISSN 1476-4687 (Electronic) 0028-0836 (Linking). doi: 10.1038/s41586-020-1969-6.

8. N. K. Hayward, J. S. Wilmott, N. Waddell, P. A. Johansson, M. A. Field, K. Nones, A. M. Patch, H. Kakavand, L. B. Alexandrov, H. Burke, V. Jakrot, S. Kazakoff, O. Holmes, C. Leonard, R. Sabarinathan, L. Mularoni, S. Wood, Q. Xu, N. Waddell, V. Tembe, G. M. Pupo, R. De Paoli-Iseppi, R. E. Vilain, P. Shang, L. M. S. Lau, R. A. Dagg, S. J. Schramm, A. Pritchard, K. Dutton-Regester, F. Newell, A. Fitzgerald, C. A. Shang, S. M. Grimmond, H. A. Pickett, J. Y. Yang, J. R. Stretch, A. Behren, R. F. Kefford, P. Hersey, G. V. Long, J. Cebon, M. Shackleton, A. J. Spillane, R. P. M. Saw, N. Lopez-Bigas, J. V. Pearson, J. F. Thompson, R. A. Scolyer, and G. J. Mann. Whole-genome landscapes of major melanoma subtypes. Nature, 545(7653):175-180, 2017. ISSN 1476-4687 (Electronic) 0028-0836 (Linking). doi: 10.1038/nature22071.

9. Network Cancer Genome Atlas. Comprehensive molecular portraits of human breast tumours. Nature, 490(7418):61-70, 2012. ISSN 1476-4687 (Electronic) 0028-0836 (Linking). doi: $10.1038 /$ nature 11412 .

10. Network Cancer Genome Atlas Research. Comprehensive genomic characterization of squamous cell lung cancers. Nature, 489(7417):519-25, 2012. ISSN 1476-4687 (Electronic) 0028-0836 (Linking). doi: 10.1038/nature11404.

11. C. W. Brennan, R. G. Verhaak, A. McKenna, B. Campos, H. Noushmehr, S. R. Salama, S. Zheng, D. Chakravarty, J. Z. Sanborn, S. H. Berman, R. Beroukhim, B. Bernard, C. J. Wu, G. Genovese, I. Shmulevich, J. Barnholtz-Sloan, L. Zou, R. Vegesna, S. A. Shukla, G. Ciriello, W. K. Yung, W. Zhang, C. Sougnez, T. Mikkelsen, K. Aldape, D. D. Bigner, E. G. Van Meir, M. Prados, A. Sloan, K. L. Black, J. Eschbacher, G. Finocchiaro, W. Friedman, D. W. Andrews, A. Guha, M. lacocca, B. P. O'Neill, G. Foltz, J. Myers, D. J. Weisenberger, R. Penny, R. Kucherlapati, C. M. Perou, D. N. Hayes, R. Gibbs, M. Marra, G. B. Mills, E. Lander, P. Spellman, R. Wilson, C. Sander, J. Weinstein, M. Meyerson, S. Gabriel, P. W. Laird, D. Haussler, G. Getz, L. Chin, and Tcga Research Network. The somatic genomic landscape of glioblastoma. Cell, 155(2):462-77, 2013. ISSN 1097-4172 (Electronic) 00928674 (Linking). doi: 10.1016/j.cell.2013.09.034.

12. J. G. Tate, S. Bamford, H. C. Jubb, Z. Sondka, D. M. Beare, N. Bindal, H. Boutselakis, C. G. Cole, C. Creatore, E. Dawson, P. Fish, B. Harsha, C. Hathaway, S. C. Jupe, C. Y. Kok, K. Noble, L. Ponting, C. C. Ramshaw, C. E. Rye, H. E. Speedy, R. Stefancsik, S. L. Thompson, S. Wang, S. Ward, P. J. Campbell, and S. A. Forbes. Cosmic: the catalogue of somatic mutations in cancer. Nucleic Acids Res, 47(D1):D941-D947, 2019. ISSN 13624962 (Electronic) 0305-1048 (Linking). doi: 10.1093/nar/gky1015.

13. E. Kang, Y. M. Kim, G. H. Seo, A. Oh, H. M. Yoon, Y. S. Ra, E. K. Kim, H. Kim, S. H. Heo, G. H. Kim, M. J. Osborn, J. Tolar, H. W. Yoo, and B. H. Lee. Phenotype categorization of neurofibromatosis type i and correlation to nf1 mutation types. J Hum Genet, 65(2):79-89, 2020. ISSN 1435-232X (Electronic) 1434-5161 (Linking). doi: 10.1038/s10038-019-0695-0.

14. T. N. Basu, D. H. Gutmann, J. A. Fletcher, T. W. Glover, F. S. Collins, and J. Downward. Aberrant regulation of ras proteins in malignant tumour cells from type 1 neurofibromatosis patients. Nature, 356(6371):713-5, 1992. ISSN 0028-0836 (Print) 0028-0836 (Linking). doi: $10.1038 / 356713 \mathrm{a} 0$.

15. H. Brems, E. Beert, T. de Ravel, and E. Legius. Mechanisms in the pathogenesis of malignant tumours in neurofibromatosis type 1. Lancet Oncol, 10(5):508-15, 2009. ISSN 1474-5488 (Electronic) 1470-2045 (Linking). doi: 10.1016/S1470-2045(09)70033-6.

16. C. M. Johannessen, E. E. Reczek, M. F. James, H. Brems, E. Legius, and K. Cichowski. The nf1 tumor suppressor critically regulates tsc2 and mtor. Proc Natl Acad Sci U S A, 102(24): 8573-8, 2005. ISSN 0027-8424 (Print) 0027-8424 (Linking). doi: 10.1073/pnas.0503224102.

17. Y. Cui, R. M. Costa, G. G. Murphy, Y. Elgersma, Y. Zhu, D. H. Gutmann, L. F. Parada, I. Mody, and A. J. Silva. Neurofibromin regulation of erk signaling modulates gaba release 
bioRxiv preprint doi: https://doi.org/10.1101/2021.02.18.431788; this version posted February 18, 2021. The copyright holder for this preprint (which was not certified by peer review) is the author/funder, who has granted bioRxiv a license to display the preprint in perpetuity. It is made available under aCC-BY 4.0 International license.

and learning. Cell, 135(3):549-60, 2008. ISSN 1097-4172 (Electronic) 0092-8674 (Linking). doi: 10.1016/j.cell.2008.09.060.

18. M. Holzel, S. Huang, J. Koster, I. Ora, A. Lakeman, H. Caron, W. Nijkamp, J. Xie, T. Callens, S. Asgharzadeh, R. C. Seeger, L. Messiaen, R. Versteeg, and R. Bernards. Nf1 is a tumor suppressor in neuroblastoma that determines retinoic acid response and disease outcome. Cell, 142(2):218-29, 2010. ISSN 1097-4172 (Electronic) 0092-8674 (Linking). doi: 10.1016/ j.cell.2010.06.004

19. M. A. Wolman, E. D. de Groh, S. M. McBride, T. A. Jongens, M. Granato, and J. A. Epstein. Modulation of camp and ras signaling pathways improves distinct behavioral deficits in a zebrafish model of neurofibromatosis type 1. Cell Rep, 8(5):1265-70, 2014. ISSN 22111247 (Electronic). doi: 10.1016/j.celrep.2014.07.054.

20. W. Yan, E. Markegard, S. Dharmaiah, A. Urisman, M. Drew, D. Esposito, K. Scheffzek, D. V. Nissley, F. McCormick, and D. K. Simanshu. Structural insights into the spred1-neurofibromin-kras complex and disruption of spred1-neurofibromin interaction by oncogenic egfr. Cell Rep, 32(3):107909, 2020. ISSN 2211-1247 (Electronic). doi: 10.1016/j.celrep.2020.107909.

21. Igor D'Angelo, Stefan Welti, Fabien Bonneau, and Klaus Scheffzek. A novel bipartite phospholipid-binding module in the neurofibromatosis type 1 protein. EMBO Reports, 7 (2):174-179, 2006. ISSN 1469221X. doi: 10.1038/sj.embor.7400602.

22. Dana Rabara, Timothy H. Tran, Srisathiyanarayanan Dharmaiah, Robert M. Stephens, Frank McCormick, Dhirendra K. Simanshu, and Matthew Holderfield. KRAS G13D sensitivity to neurofibromin-mediated GTP hydrolysis. Proceedings of the National Academy of Sciences of the United States of America, 116(44):22122-22131, 2019. ISSN 10916490. doi: 10.1073/pnas.1908353116.

23. K. Scheffzek, M. R. Ahmadian, L. Wiesmuller, W. Kabsch, P. Stege, F. Schmitz, and A. Wittinghofer. Structural analysis of the gap-related domain from neurofibromin and its implications. EMBO J, 17(15):4313-27, 1998. ISSN 0261-4189 (Print) 0261-4189 (Linking). doi: 10.1093/emboj/17.15.4313

24. K. Xie, L. A. Colgan, M. T. Dao, B. S. Muntean, L. P. Sutton, C. Orlandi, S. L. Boye, S. E. Boye, C. C. Shih, Y. Li, B. Xu, R. G. Smith, R. Yasuda, and K. A. Martemyanov. Nf1 is a direct $g$ protein effector essential for opioid signaling to ras in the striatum. Curr Biol, 26 (22):2992-3003, 2016. ISSN 1879-0445 (Electronic) 0960-9822 (Linking). doi: 10.1016/j. cub.2016.09.010

25. X. Koliou, C. Fedonidis, T. Kalpachidou, and D. Mangoura. Nuclear import mechanism of neurofibromin for localization on the spindle and function in chromosome congression. $J$ Neurochem, 136(1):78-91, 2016. ISSN 1471-4159 (Electronic) 0022-3042 (Linking). doi: $10.1111 /$ jnc. 13401 .

26. Liping Feng, Shunji Yunoue, Hiroshi Tokuo, Tatsuya Ozawa, Dongwei Zhang, Siriporn Patrakitkomjorn, Toru Ichimura, Hideyuki Saya, and Norie Araki. PKA phosphorylation and 14-3-3 interaction regulate the function of neurofibromatosis type I tumor suppressor, neurofibromin. FEBS Letters, 557(1-3):275-282, 2004. ISSN 00145793. doi: 10.1016/S0014-5793(03)01507-2.

27. D. Mangoura, Y. Sun, C. Li, D. Singh, D. H. Gutmann, A. Flores, M. Ahmed, and G. Vallianatos. Phosphorylation of neurofibromin by pkc is a possible molecular switch in egf receptor signaling in neural cells. Oncogene, 25(5):735-45, 2006. ISSN 0950-9232 (Print) 0950-9232 (Linking). doi: 10.1038/sj.onc.1209113.

28. S. H. Yoshimura and T. Hirano. Heat repeats - versatile arrays of amphiphilic helices working in crowded environments? J Cell Sci, 129(21):3963-3970, 2016. ISSN 1477-9137 (Electronic) 0021-9533 (Linking). doi: 10.1242/jcs.185710.

29. T. Dunzendorfer-Matt, E. L. Mercado, K. Maly, F. McCormick, and K. Scheffzek. The neurofibromin recruitment factor spred1 binds to the gap related domain without affecting ras inactivation. Proc Natl Acad Sci U S A, 113(27):7497-502, 2016. ISSN 1091-6490 (Electronic) 0027-8424 (Linking). doi: 10.1073/pnas.1607298113.

30. F. Cali, V. Chiavetta, G. Ruggeri, M. Piccione, A. Selicorni, D. Palazzo, M. Bonsignore, A. Cereda, M. Elia, P. Failla, M. G. Figura, A. Fiumara, S. Maitz, G. M. Luana Mandara, T. Mattina, A. Ragalmuto, C. Romano, M. Ruggieri, R. Salluzzo, A. Saporoso, C. Schepis, G. Sorge, M. Spano, G. Tortorella, and V. Romano. Mutation spectrum of nf1 gene in italian patients with neurofibromatosis type 1 using ion torrent pgm platform. Eur J Med Genet, 60(2):93-99, 2017. ISSN 1878-0849 (Electronic) 1769-7212 (Linking). doi: 10.1016/j.ejmg. 2016.11.001.

31. M. Upadhyaya, S. M. Huson, M. Davies, N. Thomas, N. Chuzhanova, S. Giovannini, D. G. Evans, E. Howard, B. Kerr, S. Griffiths, C. Consoli, L. Side, D. Adams, M. Pierpont R. Hachen, A. Barnicoat, H. Li, P. Wallace, J. P. Van Biervliet, D. Stevenson, D. Viskochil, D. Baralle, E. Haan, V. Riccardi, P. Turnpenny, C. Lazaro, and L. Messiaen. An absence of cutaneous neurofibromas associated with a 3-bp inframe deletion in exon 17 of the nf1 gene (c.2970-2972 delaat): evidence of a clinically significant nf1 genotype-phenotype correlation. Am J Hum Genet, 80(1):140-51, 2007. ISSN 0002-9297 (Print) 0002-9297 (Linking). doi: $10.1086 / 510781$.

32. M. Koczkowska, Y. Chen, T. Callens, A. Gomes, A. Sharp, S. Johnson, M. C. Hsiao, Z. Chen, M. Balasubramanian, C. P. Barnett, T. A. Becker, S. Ben-Shachar, D. R. Bertola, J. O. Blakeley, E. M. M. Burkitt-Wright, A. Callaway, M. Crenshaw, K. S. Cunha, M. Cunningham, M. D. D’Agostino, K. Dahan, A. De Luca, A. Destree, R. Dhamija, M. Eoli, D. G. R. Evans, P. Galvin-Parton, J. K. George-Abraham, K. W. Gripp, J. Guevara-Campos, N. A. Hanchard, C. Hernandez-Chico, L. Immken, S. Janssens, K. J. Jones, B. A. Keena, A. Kochhar, J. Liebelt, A. Martir-Negron, M. J. Mahoney, I. Maystadt, C. McDougall, M. McEntagart, N. Mendelsohn, D. T. Miller, G. Mortier, J. Morton, J. Pappas, S. R. Plotkin, D. Pond, K. Rosenbaum, K. Rubin, L. Russell, L. S. Rutledge, V. Saletti, R. Schonberg, A. Schreiber, M. Seidel, E. Siqveland, D. W. Stockton, E. Trevisson, N. J. Ullrich, M. Upadhyaya, R. van Minkelen, H. Verhelst, M. R. Wallace, Y. S. Yap, E. Zackai, J. Zonana, V. Zurcher, K. Claes, Y. Martin, B. R. Korf, E. Legius, and L. M. Messiaen. Genotype-phenotype correlation in nf1: Evidence for a more severe phenotype associated with missense mutations affecting nf1 codons 844-848. Am J Hum Genet, 102(1):69-87, 2018. ISSN 1537-6605 (Electronic) 0002-9297 (Linking). doi: 10.1016/j.ajhg.2017.12.001.

33. E. Cerami, J. Gao, U. Dogrusoz, B. E. Gross, S. O. Sumer, B. A. Aksoy, A. Jacobsen, C. J. Byrne, M. L. Heuer, E. Larsson, Y. Antipin, B. Reva, A. P. Goldberg, C. Sander, and N. Schultz. The cbio cancer genomics portal: an open platform for exploring multidimen- sional cancer genomics data. Cancer Discov, 2(5):401-4, 2012. ISSN 2159-8290 (Electronic) 2159-8274 (Linking). doi: 10.1158/2159-8290.CD-12-0095.

34. D. Tegunov and P. Cramer. Real-time cryo-electron microscopy data preprocessing with warp. Nat Methods, 16(11):1146-1152, 2019. ISSN 1548-7105 (Electronic) 1548-7091 (Linking). doi: 10.1038/s41592-019-0580-y.

35. A. Punjani, J. L. Rubinstein, D. J. Fleet, and M. A. Brubaker. cryosparc: algorithms for rapid unsupervised cryo-em structure determination. Nat Methods, 14(3):290-296, 2017. ISSN 1548-7105 (Electronic) 1548-7091 (Linking). doi: 10.1038/nmeth.4169.

36. S. Q. Zheng, E. Palovcak, J. P. Armache, K. A. Verba, Y. Cheng, and D. A. Agard. Motioncor2: anisotropic correction of beam-induced motion for improved cryo-electron microscopy. Nat Methods, 14(4):331-332, 2017. ISSN 1548-7105 (Electronic) 1548-7091 (Linking). doi: 10.1038/nmeth. 4193 .

37. A. Rohou and N. Grigorieff. Ctffind4: Fast and accurate defocus estimation from electron micrographs. J Struct Biol, 192(2):216-21, 2015. ISSN 1095-8657 (Electronic) 1047-8477 (Linking). doi: 10.1016/j.jsb.2015.08.008.

38. T. Wagner and S. Raunser. The evolution of sphire-cryolo particle picking and its application in automated cryo-em processing workflows. Commun Biol, 3(1):61, 2020. ISSN 2399-3642 (Electronic) 2399-3642 (Linking). doi: 10.1038/s42003-020-0790-y.

39. J. Zivanov, T. Nakane, B. O. Forsberg, D. Kimanius, W. J. Hagen, E. Lindahl, and S. H. Scheres. New tools for automated high-resolution cryo-em structure determination in relion3. Elife, 7, 2018. ISSN 2050-084X (Electronic) 2050-084X (Linking). doi: 10.7554/eLife. 42166 .

40. K. Ramlaul, C. M. Palmer, T. Nakane, and C. H. S. Aylett. Mitigating local over-fitting during single particle reconstruction with sidesplitter. J Struct Biol, 211(2):107545, 2020. ISSN 1095-8657 (Electronic) 1047-8477 (Linking). doi: 10.1016/j.jsb.2020.107545.

41. T. Grant, A. Rohou, and N. Grigorieff. cistem, user-friendly software for single-particle image processing. Elife, 7, 2018. ISSN 2050-084X (Electronic) 2050-084X (Linking). doi: 10.7554/ eLife. 35383

42. G. Tang, L. Peng, P. R. Baldwin, D. S. Mann, W. Jiang, I. Rees, and S. J. Ludtke. Eman2: an extensible image processing suite for electron microscopy. J Struct Biol, 157(1):38-46, 2007. ISSN 1047-8477 (Print) 1047-8477 (Linking). doi: 10.1016/j.jsb.2006.05.009.

43. P. Emsley and K. Cowtan. Coot: model-building tools for molecular graphics. Acta Crystallogr D Biol Crystallogr, 60(Pt 12 Pt 1):2126-32, 2004. ISSN 0907-4449 (Print) 0907-4449 (Linking). doi: 10.1107/S0907444904019158.

44. P. D. Adams, P. V. Afonine, G. Bunkoczi, V. B. Chen, I. W. Davis, N. Echols, J. J. Headd, L. W. Hung, G. J. Kapral, R. W. Grosse-Kunstleve, A. J. McCoy, N. W. Moriarty, R. Oeffner, R. J. Read, D. C. Richardson, J. S. Richardson, T. C. Terwilliger, and P. H. Zwart. Phenix: a comprehensive python-based system for macromolecular structure solution. Acta Crystallogr D Biol Crystallogr, 66(Pt 2):213-21, 2010. ISSN 1399-0047 (Electronic) 0907-4449 (Linking). doi: 10.1107/S0907444909052925.

45. T. I. Croll. Isolde: a physically realistic environment for model building into low-resolution electron-density maps. Acta Crystallogr D Struct Biol, 74(Pt 6):519-530, 2018. ISSN 20597983 (Electronic) 2059-7983 (Linking). doi: 10.1107/S2059798318002425.

46. Bing Yang, Yan Jie Wu, Ming Zhu, Sheng Bo Fan, Jinzhong Lin, Kun Zhang, Shuang Li, Hao Chi, Yu Xin Li, Hai Feng Chen, Shu Kun Luo, Yue He Ding, Le Heng Wang, Zhiqi Hao, Li Yun Xiu, She Chen, Keqiong Ye, Si Min He, and Meng Qiu Dong. Identification of cross-linked peptides from complex samples. Nature Methods, 9(9):904-906, 2012. ISSN 15487091. doi: 10.1038/nmeth.2099.

47. Martin Krzywinski, Jacqueline Schein, Inanc Birol, Joseph Connors, Randy Gascoyne, Doug Horsman, Steven J. Jones, and Marco A. Marra. Circos: An information aesthetic for comparative genomics. Genome Research, 19(9):1639-1645, 2009. ISSN 10889051. doi: 10.1101 /gr.092759.109.

48. S. Mondal, K. Hsiao, and S. A. Goueli. A homogenous bioluminescent system for measuring gtpase, gtpase activating protein, and guanine nucleotide exchange factor activities. Assay Drug Dev Technol, 13(8):444-55, 2015. ISSN 1557-8127 (Electronic) 1540-658X (Linking). doi: 10.1089/adt.2015.643.

49. P. Schuck. Size-distribution analysis of macromolecules by sedimentation velocity ultracentrifugation and lamm equation modeling. Biophys J, 78(3):1606-19, 2000. ISSN 0006-3495 (Print) 0006-3495 (Linking). doi: 10.1016/S0006-3495(00)76713-0.

50. Yasset Perez-Riverol, Attila Csordas, Jingwen Bai, Manuel Bernal-Llinares, Suresh Hewapathirana, Deepti J. Kundu, Avinash Inuganti, Johannes Griss, Gerhard Mayer, Martin Eisenacher, Enrique Pérez, Julian Uszkoreit, Julianus Pfeuffer, Timo Sachsenberg, Şule Yilmaz, Shivani Tiwary, Jürgen Cox, Enrique Audain, Mathias Walzer, Andrew F. Jarnuczak, Tobias Ternent, Alvis Brazma, and Juan Antonio Vizcaíno. The PRIDE database and related tools and resources in 2019: Improving support for quantification data. Nucleic Acids Research, 47(D1):D442-D450, 2019. ISSN 13624962. doi: 10.1093/nar/gky1106.

51. P. V. Hornbeck, B. Zhang, B. Murray, J. M. Kornhauser, V. Latham, and E. Skrzypek. Phosphositeplus, 2014: mutations, ptms and recalibrations. Nucleic Acids Res, 43 (Database issue):D512-20, 2015. ISSN 1362-4962 (Electronic) 0305-1048 (Linking). doi: $10.1093 / \mathrm{nar} / \mathrm{gku} 1267$

52. P. V. Hornbeck, B. Zhang, B. Murray, J. M. Kornhauser, V. Latham, and E. Skrzypek. Phosphositeplus, 2014: mutations, ptms and recalibrations. Nucleic Acids Res, 43 (Database issue):D512-20, 2015. ISSN 1362-4962 (Electronic) 0305-1048 (Linking). doi: 10.1093/nar/gku1267.

53. H. Ashkenazy, S. Abadi, E. Martz, O. Chay, I. Mayrose, T. Pupko, and N. Ben-Tal. Consurf 2016: an improved methodology to estimate and visualize evolutionary conservation in macromolecules. Nucleic Acids Res, 44(W1):W344-50, 2016. ISSN 1362-4962 (Electronic) 0305-1048 (Linking). doi: 10.1093/nar/gkw408. 
bioRxiv preprint doi: https://doi.org/10.1101/2021.02.18.431788; this version posted February 18, 2021. The copyright holder for this preprint (which was not certified by peer review) is the author/funder, who has granted bioRxiv a license to display the preprint in perpetuity. It is made available under aCC-BY 4.0 International license.

a

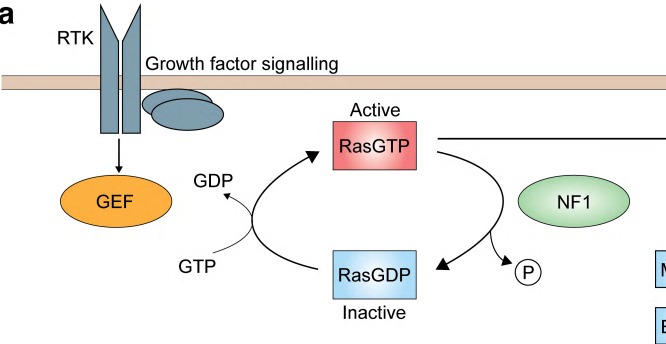

c

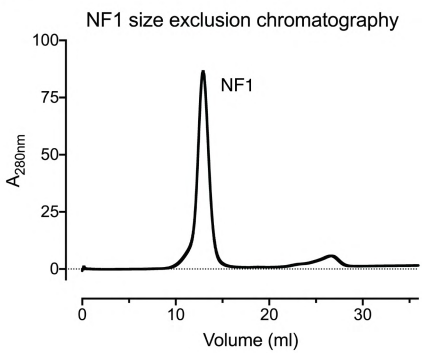

d

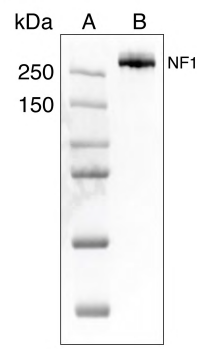

b

\begin{tabular}{|ll|}
\hline \multicolumn{2}{l|}{ Select binding proteins/effectors } \\
RAS & CMP-2 \\
SPRED1 & FAK \\
PI & ETEA \\
LRPPRC & SAG/CUL1/FBXW7 \\
Kinesin-1 & Cullin 3 \\
APP & Caveolin-1 \\
LIMK2 & Syndecan \\
Tubulin & DDAH \\
VCP & $14-3-3$ \\
\hline
\end{tabular}

f

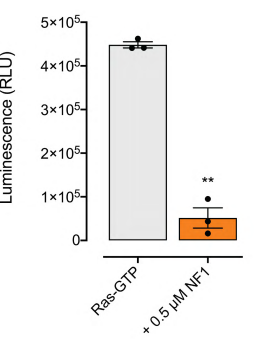

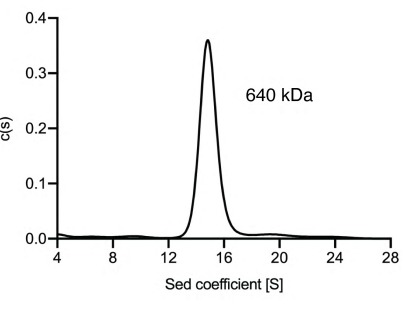

Fig. S1. Purification and biochemical characterisation of the NF1 dimer. a. Schematic of the inhibitory role of NF1 in RAS signalling. b. Select NF1 binding partners and cellular effectors are listed(2). c. NF1 purifies as a single peak by size-exclusion chromatography. d. Purified recombinant NF1 is highly pure by SDS-PAGE. e. NF1 accelerates the hydrolysis of GTP by KRAS. Hydrolysis was measured using a GTPase-Glo kit (Promega) to detect the amount of GTP remaining in the reaction after incubation. ${ }^{* *} \mathrm{p}<0.01$ versus Ras-GTP alone, paired two-tailed t-test. f. Sedimentation velocity analytical ultracentrifugation analysis indicates that NF1 likely forms a homodimer in solution (calculated molecular weight of $640 \mathrm{kDa}$, r.m.s.d. 0.004). 
bioRxiv preprint doi: https://doi.org/10.1101/2021.02.18.431788; this version posted February 18, 2021. The copyright holder for this preprint (which was not certified by peer review) is the author/funder, who has granted bioRxiv a license to display the preprint in perpetuity. It is made available under aCC-BY 4.0 International license.

$\mathbf{a}$

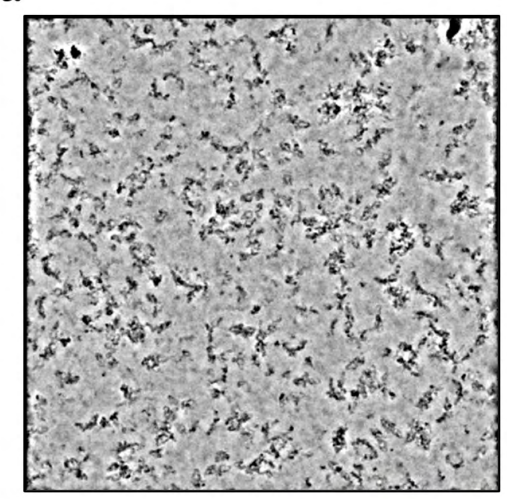

b
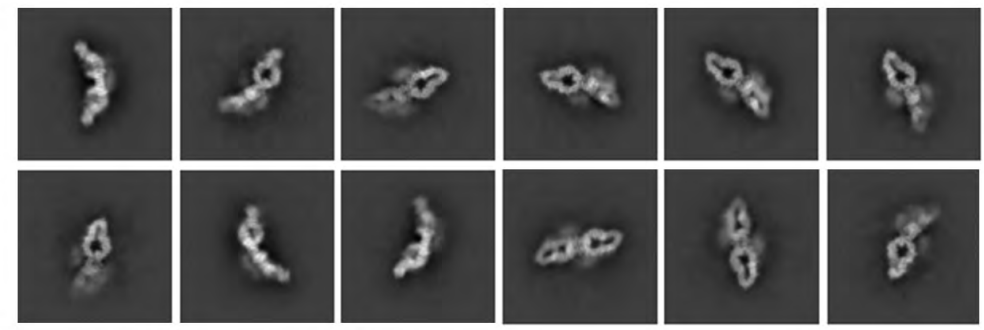

C
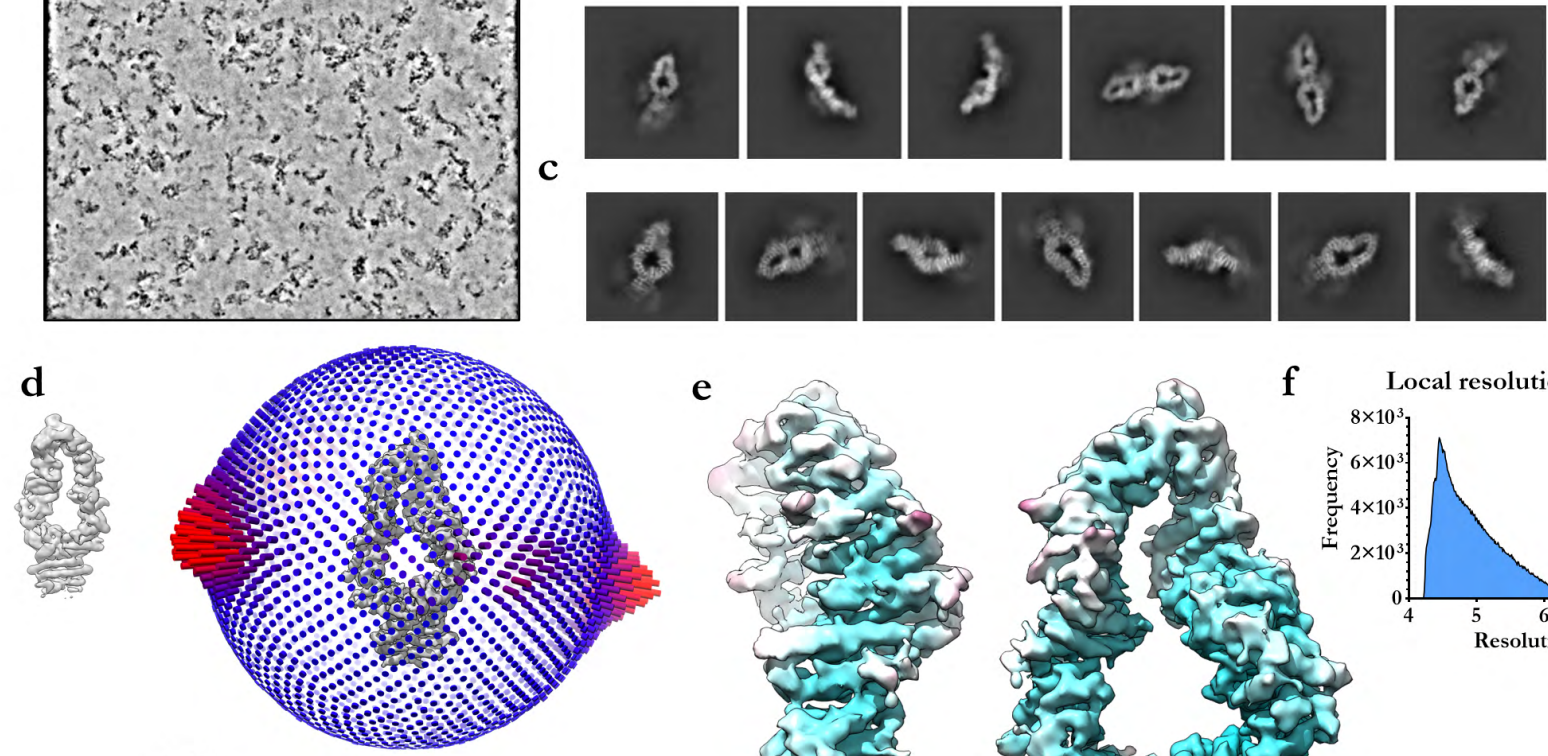

e
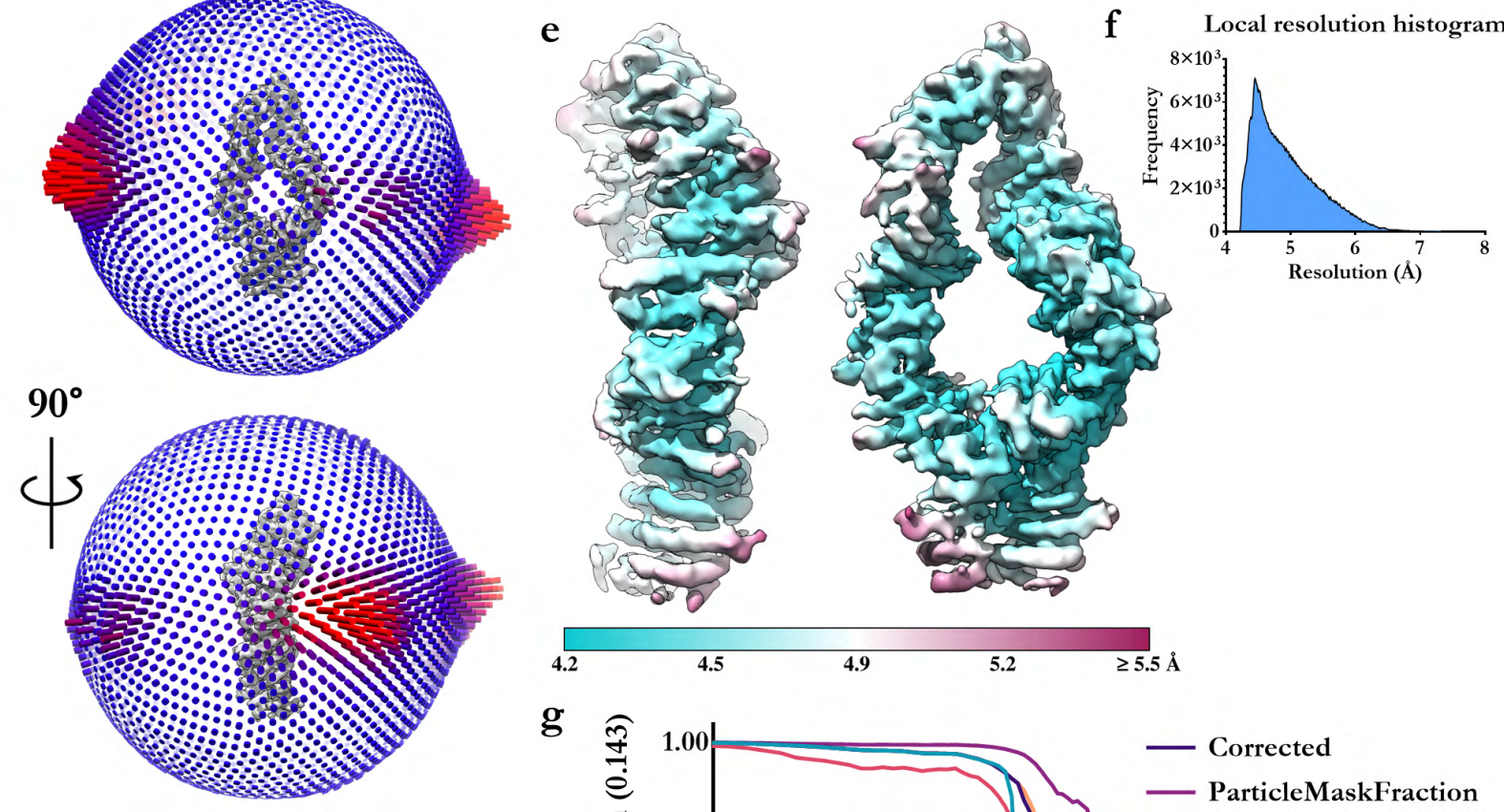

\section{g}

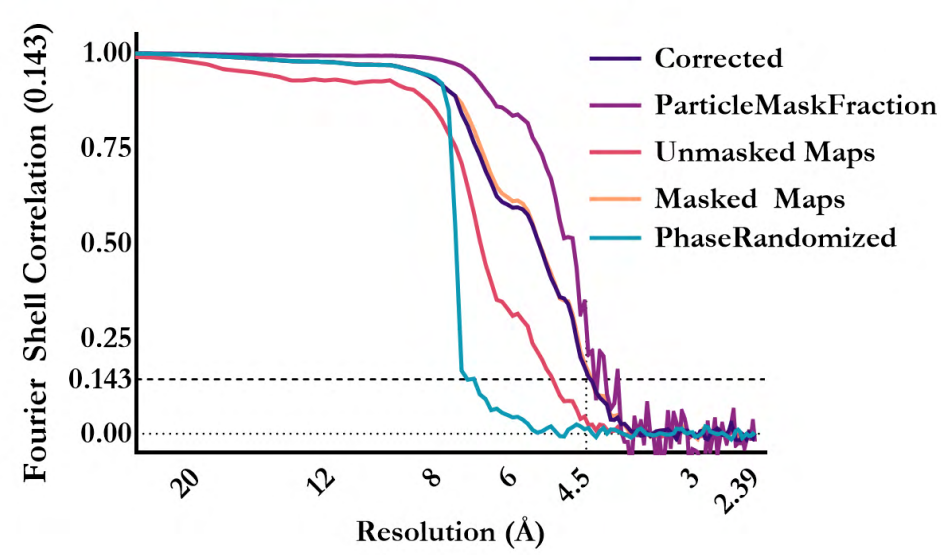

Fig. S2. Cryo-EM summary and validation for the NF1 wing localised reconstruction. a. A representative denoised micrograph of NF1 collected on a Talos Arctica 200 kV. b. Selected 2D class averages of the NF1 dimer. Diffuse signal can be observed at the central interface corresponding to flexible GRD/SEC/PH domains. c. Select $2 \mathrm{D}$ class averages of symmetry expanded, localised reconstructions of a single NF1 dimer lobe. $\mathbf{d}$. Angular distribution of the final localised reconstruction, shown beside is the corresponding orientation of the reconstruction for clarity. e. The NF1 dimer lobe coloured by local resolution. f. Distribution of voxels as a function of local resolution. The majority of voxels are resolved to a mode value of $\sim 4.5 \AA$. g. The Fourier shell correlation plot estimates a global resolution of $4.5 \AA$. 
bioRxiv preprint doi: https://doi.org/10.1101/2021.02.18.431788; this version posted February 18, 2021. The copyright holder for this preprint (which was not certified by peer review) is the author/funder, who has granted bioRxiv a license to display the preprint in perpetuity. It is made available under aCC-BY 4.0 International license.
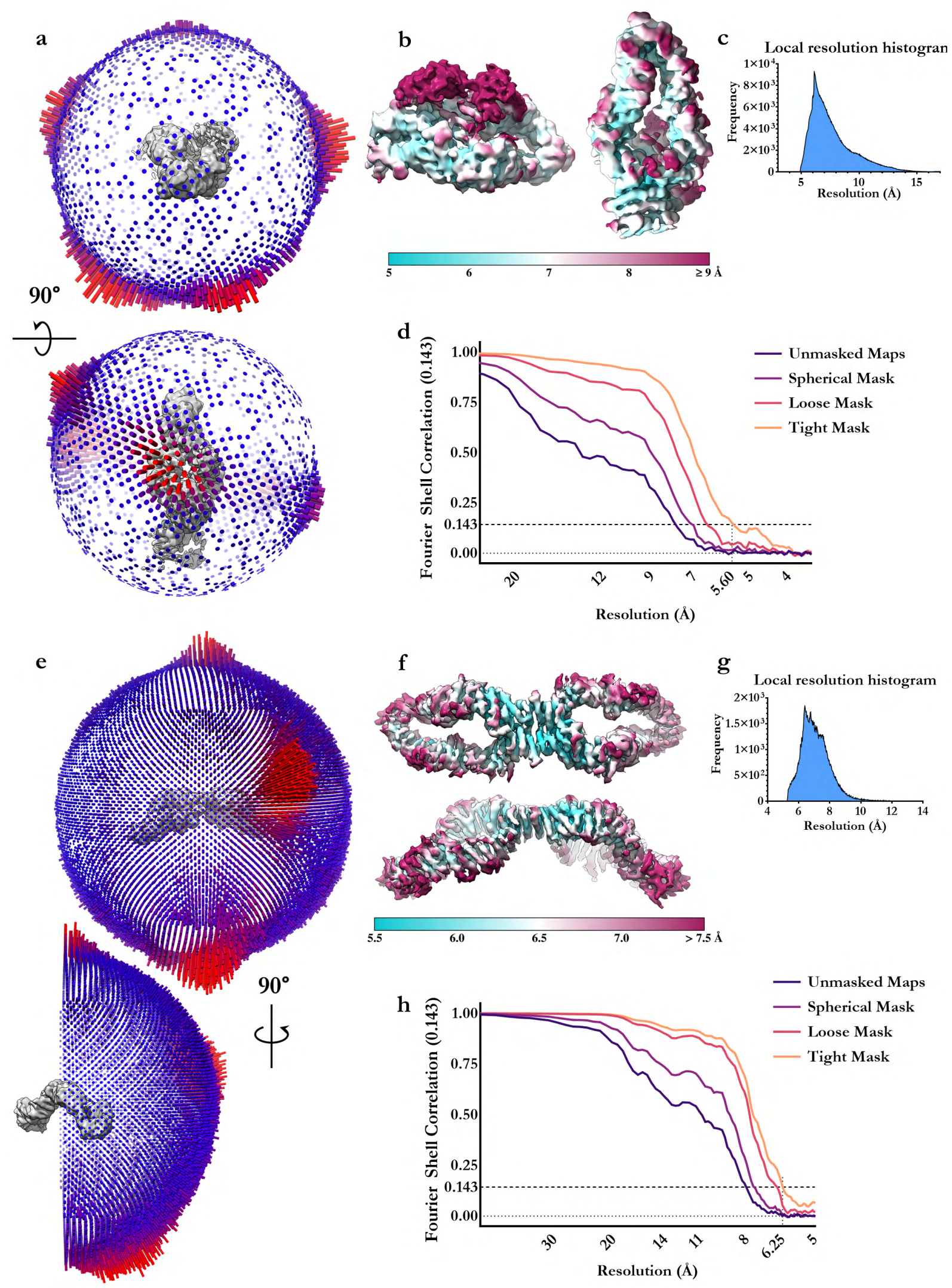

Fig. S3. Cryo-EM summary and validation for the reconstructions of NF1 autoinhibited and dimeric states. a. Angular distribution of the autoinhibited NF1 localised reconstruction, $\mathbf{b}$., and local resolution analysis. c. Frequency distribution of voxels as a function of local resolution for the autoinhibited NF1 localised reconstruction. $\mathbf{d}$. The Fourier shell correlation plot estimates a global resolution of $5.6 \AA$ A. e, f, g. As in $\mathbf{a}, \mathbf{b}, \mathbf{c}$. for the full NF1 homodimer. $\mathbf{h}$. The Fourier shell correlation plot estimates a global resolution of $6.3 \AA$. 
bioRxiv preprint doi: https://doi.org/10.1101/2021.02.18.431788; this version posted February 18, 2021. The copyright holder for this preprint (which was not certified by peer review) is the author/funder, who has granted bioRxiv a license to display the preprint in perpetuity. It is made available under aCC-BY 4.0 International license.

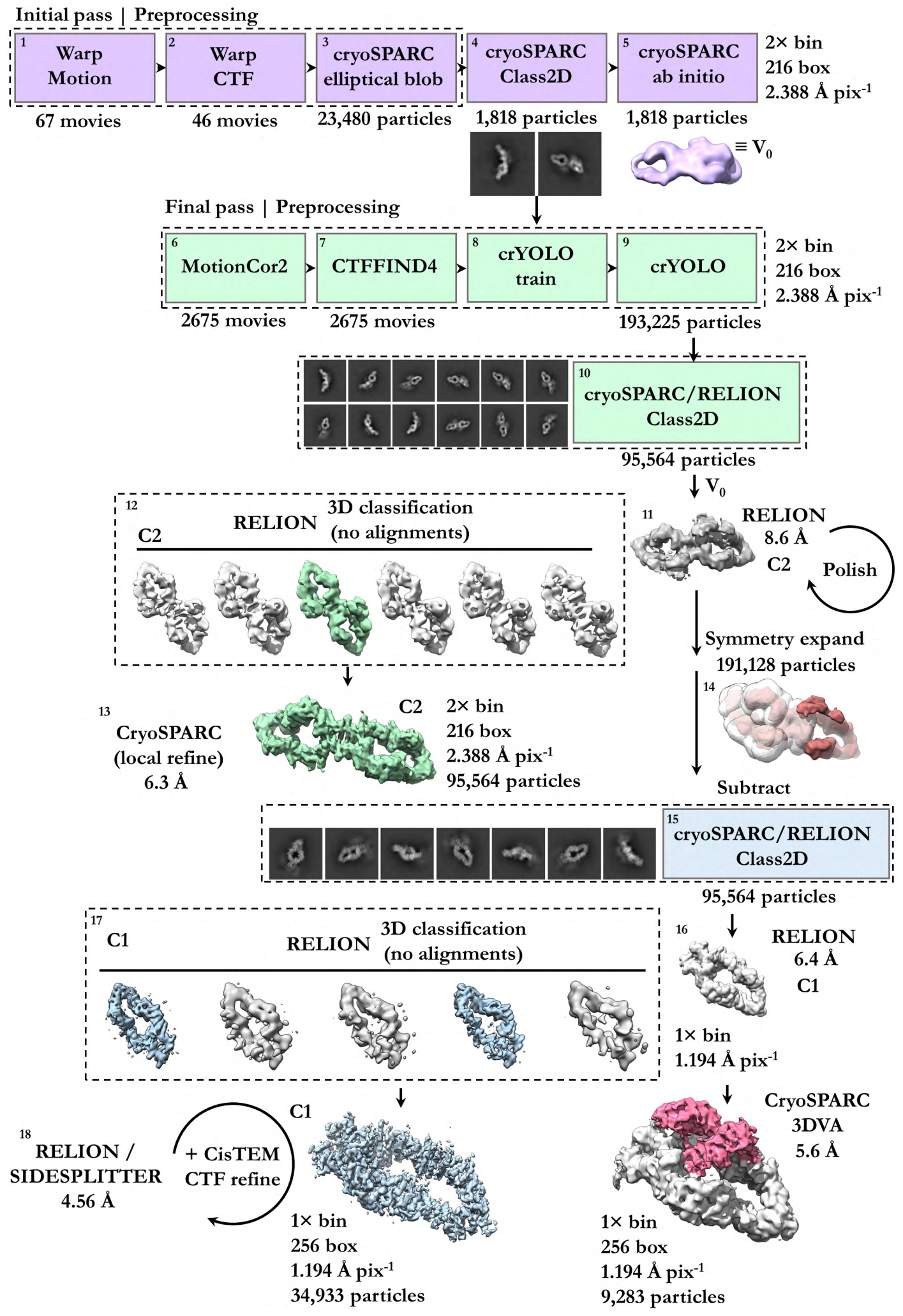

Fig. S4. Cryo-EM data analysis and flowchart. Initial cryo-EM analysis is indicated in purple. Subsequent analysis of the whole dataset give rise to a $7.5 \AA$ reconstruction of the NF1 dimer (green). Symmetry expansion and signal subtraction were utilised to generate a focused refinement of a single NF1 lobe (light blue) to overcome significant continuous conformational heterogeneity. The final $4.6 \AA$ reconstruction was later fitted into the NF1 dimer reconstruction to yield a composite map. Variational analysis revealed a small discrete population of NF1 particles with resolved GRD and SEC-PH domains (red) in an autoinhibited conformation. 
bioRxiv preprint doi: https://doi.org/10.1101/2021.02.18.431788; this version posted February 18, 2021. The copyright holder for this preprint (which was not certified by peer review) is the author/funder, who has granted bioRxiv a license to display the preprint in perpetuity. It is made available under aCC-BY 4.0 International license.

a
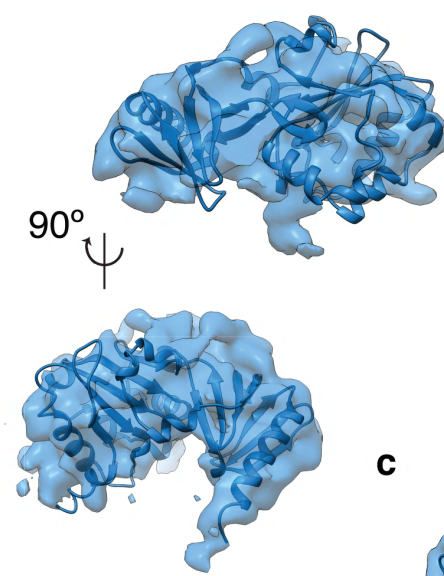

b

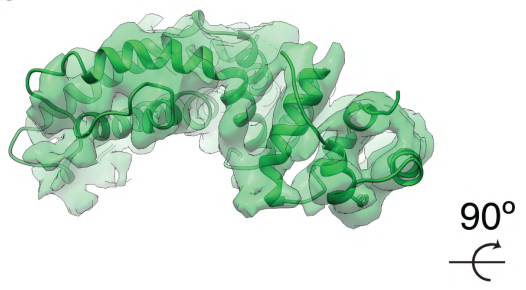

d
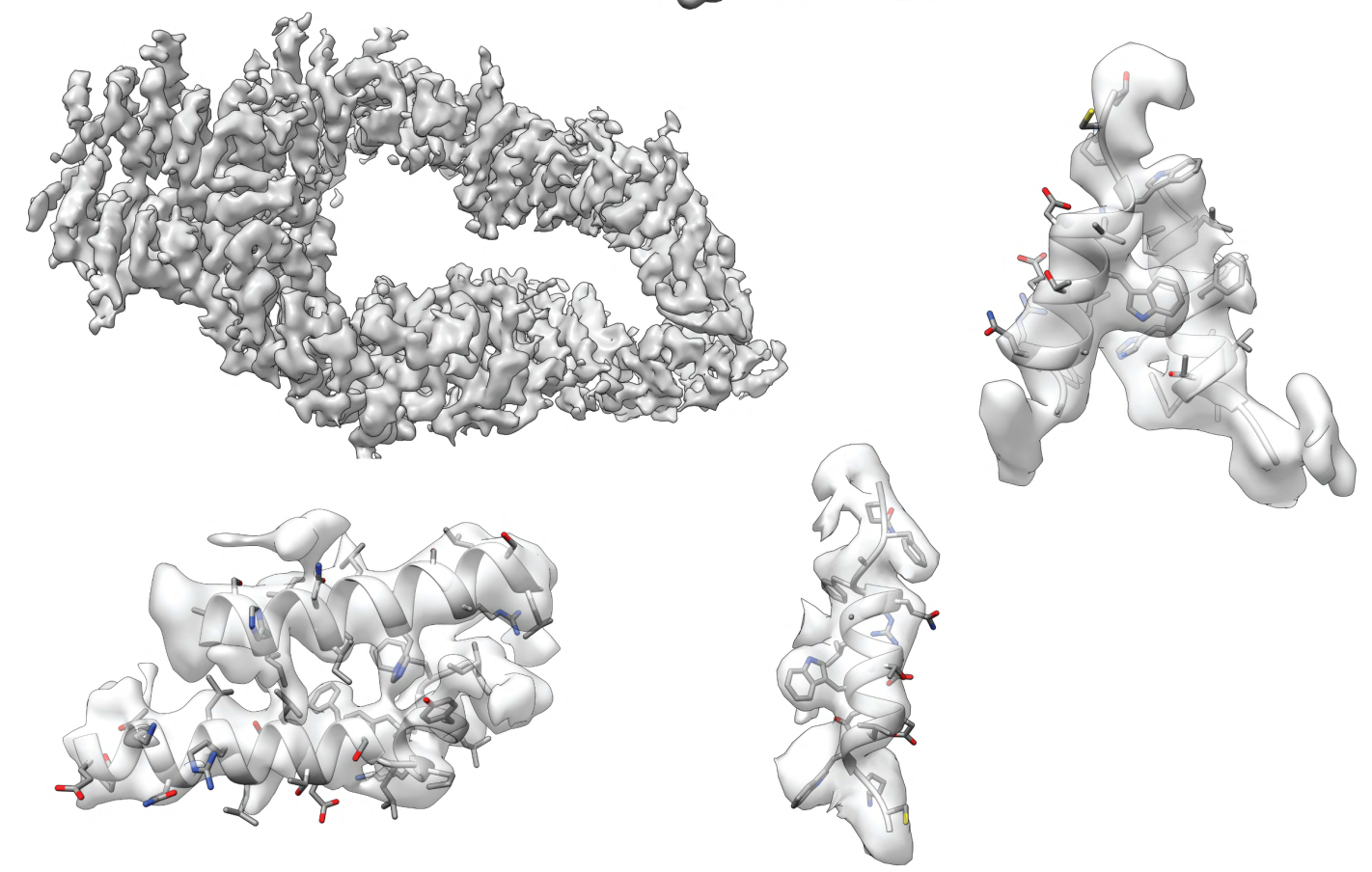

Fig. S5. Map to model fit. a. Map-to-model fit of the SEC-PH domain (blue). b. Map-to-model fit of the GRD domain, clearly resolved secondary structure is evident. c. The autoinhibited conformation of NF1, GRD (green) and SEC-PH (blue) domains are well resolved against the scaffold. $d$. The sharpened $4.6 \AA$ reconstruction of the core NF1 scaffold and select regions of density illustrating clearly resolved side chains. 
bioRxiv preprint doi: https://doi.org/10.1101/2021.02.18.431788; this version posted February 18, 2021. The copyright holder for this preprint (which was not certified by peer review) is the author/funder, who has granted bioRxiv a license to display the preprint in perpetuity. It is made available under aCC-BY 4.0 International license.

a

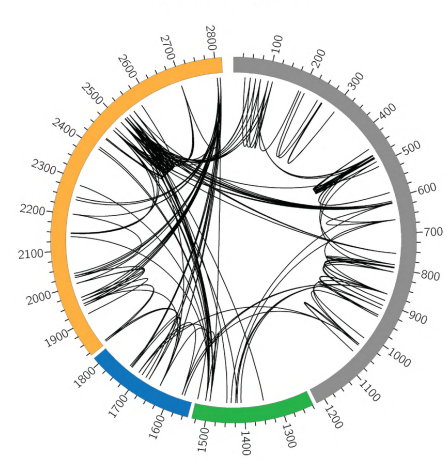

$\mathrm{BS}^{3}$ crosslinks

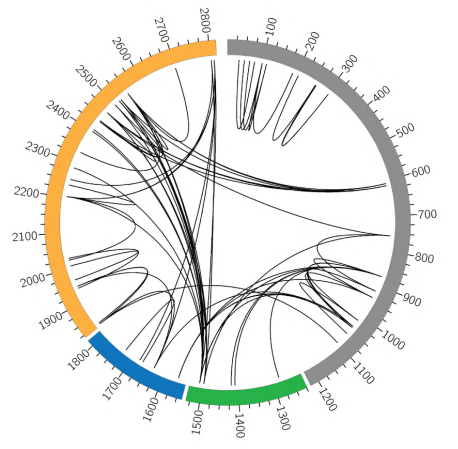

C

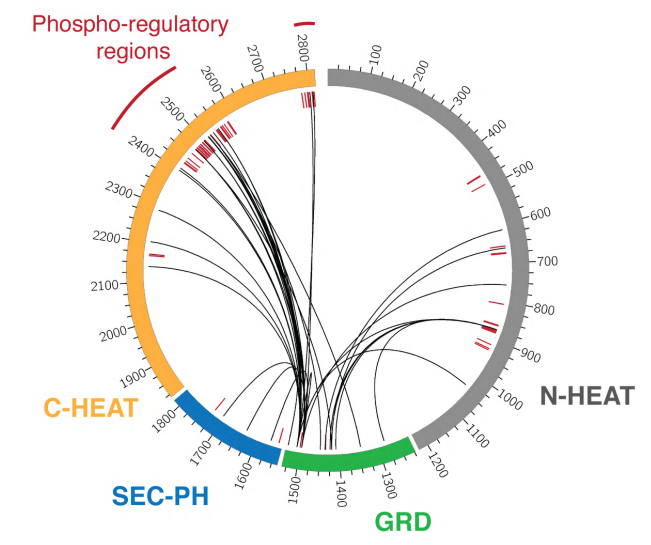

d

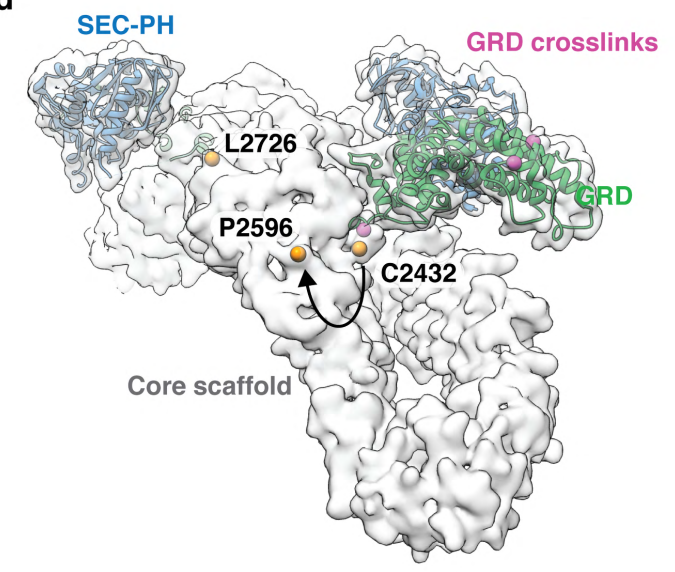

Fig. S6. Crosslinking mass spectrometry of NF1 a. Crosslinking mass spectrometry identified a total of 174 BS $^{2} \mathrm{G}$ crosslinks and $72 \mathrm{BS}^{3}$ crosslinks within the NF1 dimer. b. Mapping of the $\mathrm{BS}^{2} \mathrm{G}$ crosslinks onto the NF1 structure revealed that the majority of all crosslinks mapped to allowable regions of the NF1 model. C $\alpha$ carbons of crosslinked residues are shown as spheres and lines indicate crosslinked residues. c. Circos plot highlighting all BS ${ }^{3}$ and $B S^{2} G$ crosslinks observed between the GRD domain and the rest of the NF1 molecule. GRD crosslinked regions map remarkably well to the two known NF1 phosphorylation clusters(51). Known NF1 phosphorylation sites(52) are indicated as dashed red lines on the inside of the circos plot. d. Although these regions are too flexible to appear in the cryo-EM maps, they are each situated adjacent to the GRDs and appear poised to further regulate either the conformation of the GRD or membrane binding capacity. Structural representation of the NF1 surface with the GRD and SEC-PH domains in cartoon format. The C $\alpha$ carbon of the exit (C2432) and entry (P2596) residue of the main phospho-regulatory loop are indicated as yellow spheres. The $\mathrm{C} \alpha$ carbon of the final resolved residue of the C-terminus (L2726) is also indicated as a yellow sphere. C $\alpha$ carbons on the GRD that crosslink to the phosphoregulatory loops are indicated as pink spheres. 
bioRxiv preprint doi: https://doi.org/10.1101/2021.02 18.431788; this version posted February 18 2021. The copyright holder for this preprint (which was not certified by peer review) is the author/funder, who has granted bioRxiv a license to display the preprint in perpetuity. It is made available under aCC-BY 4.0 International license.

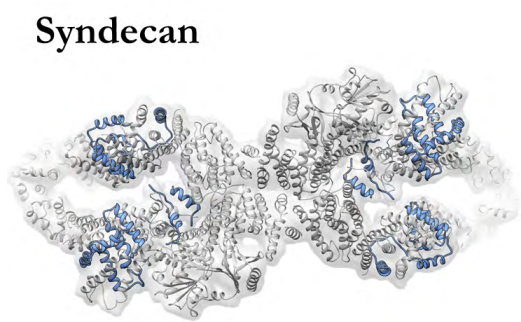

DDAH

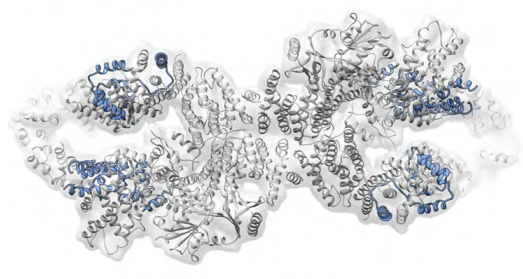

APP/ETEA/RAS

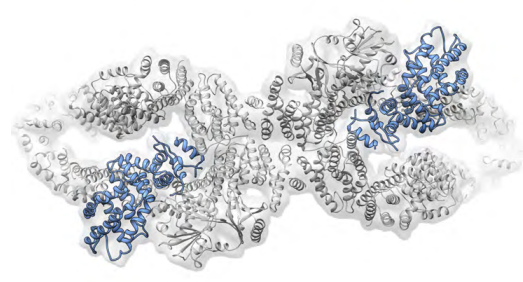

\section{Tubulin/LRPPRC}

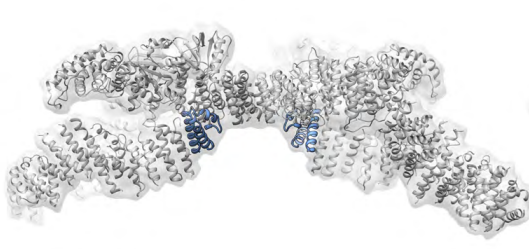

LIMK2

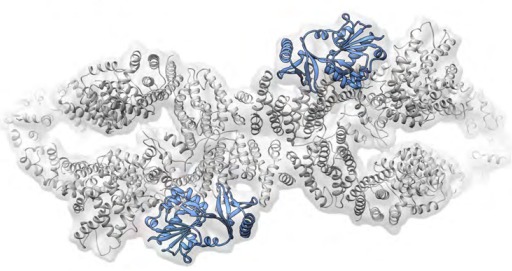

VCP

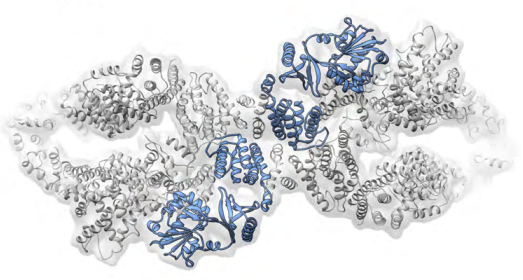

\section{CRMP2/FAK/14-3-3}

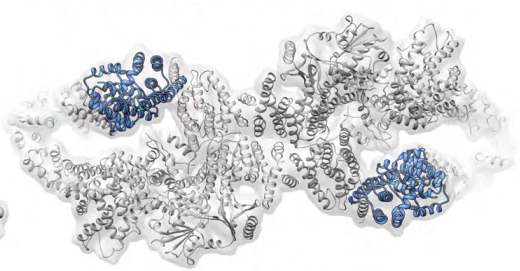

SAG/CUL1/FBXW7

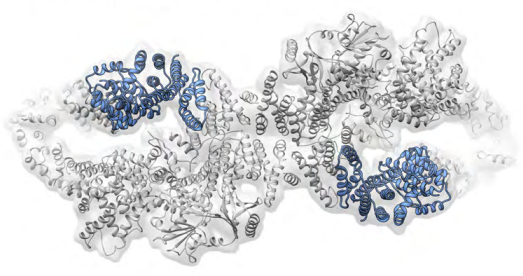

Fig. S7. Mapping of known binding sites to the NF1 structure. The position of select binding partners of NF1 (grey) are mapped onto the structure (blue)(2).

$\mathbf{a}$

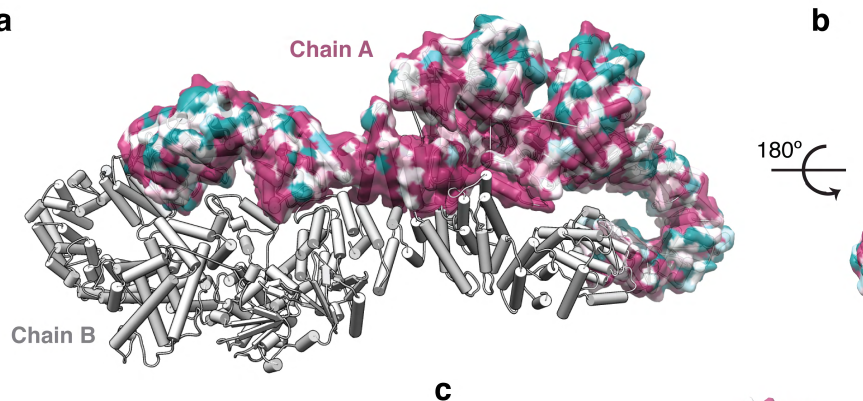

C b

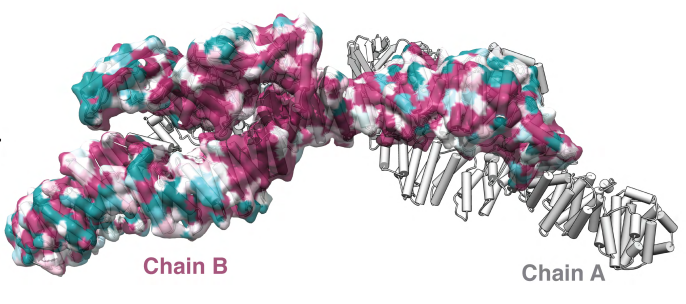

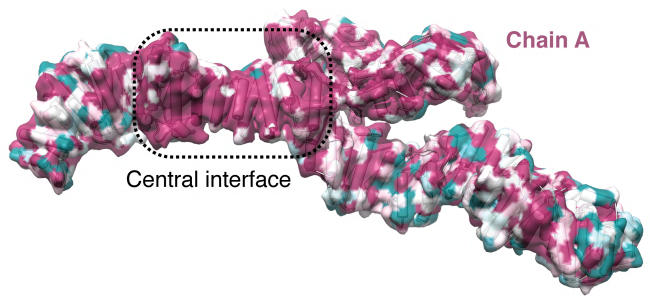

Fig. S8. Surface conservation of NF1. NF1 surface conservation analysed using ConSurf(53). a. The NF1 dimer with surface conservation mapped to a single chain. b. $\mathrm{NF} 1$ rotated $180^{\circ}$ to show surface conservation of the second chain. c. A single NF1 chain displayed to show the conserved central interface. 
bioRxiv preprint doi: https://doi.org/10.1101/2021.02.18.431788; this version posted February 18, 2021. The copyright holder for this preprint (which was not certified by peer review) is the author/funder, who has granted bioRxiv a license to display the preprint in perpetuity. It is made available under aCC-BY 4.0 International license.

Homo_sapiens Mus musculus Rat̄̄us norvegicus Gallus gallus Drosophila_melanogaster

Homo sapiens Mus musculus Rat̄̄us norvegicus Gallus_gallus Drosophila_melanogaster

Homo sapiens Mus musculus Rattus_norvegicus Gallus gallus Drosophila melanogaster

Homo_sapiens Mus musculus Rattus norvegicus Gallus gallus Drosophila_melanogaster

Homo_sapiens Mus musculus Rattus norvegicus Gallus gallus Drosophila_melanogaster

Homo sapiens Mus musculus Rattus_norvegicus Gallus_gallus Drosophila melanogaster

Homo_sapiens Mus_musculus Rattus norvegicus Gallus_gallus Drosophila melanogaster

Homo_sapiens Mus musculus Rattus norvegicus Gallus gallus Drosophila_melanogaster

Homo_sapiens Mus musculus Ratēus norvegicus Gallus gallus Drosophila_melanogaster

Homo_sapiens Mus musculus RatĒus_norvegicus Gallus_gallus Drosophila_melanogaster

Homo sapiens Mus_musculus Rattus norvegicus Gallus gallus Drosophila melanogaster

Homo_sapiens Mus musculus Rattus norvegicus Gallus gallus Drosophila_melanogaster

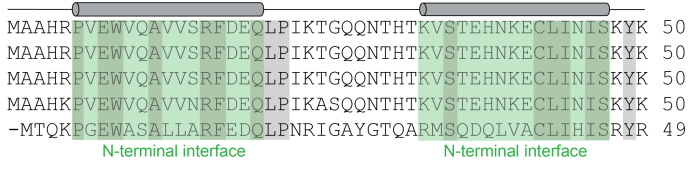

FSLVISGLTTILKNVNNMRIFGEAAEKN-LYLSOLIILDTLEKCLAGQPK 99 FSLVISGLTTILKNVNNMRIFGEAAEKN-LYLSOLIILDTLEKCLAGQPK 99 FSLVISGLTTILKNVNNMRIFGEAAEKN-LYLSQLIILDTLEKCLAGQPK 99 FSLVISGLTNILKNVNNMRIFGETAEKN-LYLSQLIILDTLEKCLAGQPK 99 FSLVISGLTKMLQRVNEAALQNRHEPERCYFESLVIILTTLERCLTNQTK 99

DTMRLDETMLVKQLLPEICHFLHTCREGNQHAAELRNSASGVLFSLSCNN 149 $\begin{array}{ll}\text { DTMRLDETMLVKQLLPEICHFLHTCREGNQHAAELRNSASGVLESLSCNN } & 149 \\ \text { DTMRLDETMLVKQLLPEICHFLHTCREGNQHAAELRNSASGVLFSLSCNN } & 149\end{array}$ DTMRLDETMLVKQLLPEICHFLHTCREGNQHAAELRNSASGVLFSLSCNN 149
DTMRLDETMLVKQLLPEICHFLHTCREGNQHAAELRNSASGVLFSLSCNN 149 DTMRLDETMLVKQLLPE ICHF I HTYREGNQHAAELRNSASGVLFSLSCNN 149 DTARFEEAMNVKLLLREISQFVDVQSDSNPNAAQLKALASKVLFALSONH 149

FNAVFSRISTRLQELTVCSEDNVDVHDIELLQY INVDCAKLKRLLKETAF 199 FNAVFSRISTRLQELTVCSEDNVDVHDIELLQYINVDCAKLKRLLKETAF 199 FNAVESRISTRLQELTVCSEDNVDVHDIELLOYINVDCAKLKRLLKETAF 199 FNAVFSRISTRLQELTVCSEDNADVHDIELLOYISVDCSKLKRLLQETVF 199 FSAVFNRISARIOELTSCSEENPDYNDIELIOHIDMDMIKLTKLLOETIT 199

KFKALKKVAQLAVINSLEKAFWNWVENYPDEFTKLYQIPQTDMAECAEKL 249 KFKALKKVAQLAVINSLEKAFWNWVENYPDEFTKLYQIPQTDMAECAEKL 24 KFKALKKVAQLAVINSLEKAFWNWVENYPDEFTKLYOIPOTDMAECAGKL 249 KEKALKKVAQLAVINSLEKAFWNWVENYPDEFTKLYQTPQTDMADCAEKL 249 KERSKR-APPLILLYSLEKAIWNWIEYHPQEFQDLQRGTNRDISTCWEPL 248

FDLVDGFAES-TKRKAAVWPLQI I LLILCPEI IQDISKDVV--------- 289 FDLVDGEAES-TKRKAAVWPLQI I LLI LCPEI IQDISKDVV--------- 289 FDLVDGFAES-TKRKAAVWPLQI I LLILCPEI IQDISRDVV--------- 289 FDLVDGEAES-TKRKAAVWPLQI I LLVLCPEI IQDIAKDVV---------- 289 MDFVEYFKTENKKSKTLVWPLQMLLLILNPSCLEAVVNELQQSEKEKEKD 298

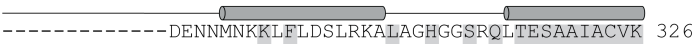
---------DESNINKKLFLDSLRKALAGHGGSRQLTESAAIACVK 326 ----------DENNTNKKLFLDSLRKALAGHGGSRQLTESAAIACVK 326 ----------EETKMNKKLFLDNLRKALAGHSGSRQLTESAAIACVK 326 KEKVASKSAQSTSRDKDFSAKQFIESIKRGLGQHSPSKQVTESAAIACVK 348

373 LCKASTY INWED-NSVIFLLVQSMVVDLKNLLFNPSKPFSRGSQ--PADV 373 LCKASTY INWED-NSVIFLLVQSMVVDLKNLLFNPSKPFSRGSQ--PADV 373 LCKASTYINWED-NSVI FLLVOSMVVDLKNLIFNPSKPFSRSNQ--NADV 373 LCKASTY INNTDSNNVVFKLVQFFINDLKALLFNPAKPFSRGQGYNFADI 398

DLMIDCLVSCFRISPHNNQHFKICLAQNSPSTFHYVLVNSLH-------- 415 DLMIDCLVSCFRISPHNNOHFKICLAONSPSTFHYVLVNSLH-------- 415 DLMIDCLVSCFRISPHNNQHFKICLAQNSPSTFHYVLVNSLH-------- 415 DLMIDCLVSCFRINPHNNQHFKICLAQSSPSTFHYVLVNSLH-------- 415 ELMIDCWVSCFRINPHNIEALKVCLNLSSPQAYHFVIVCSLLRLAHIYVD 448

RIITNSALDWWPKIDAVYCHSVELRNMFGETLHKAVQGCGA 456

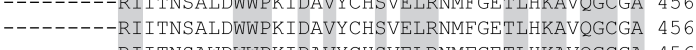
-------RIITNSAWDWWPKIDAVYCHSVELRNMFGETLHKAVQGCGA 456 --------RIITNSALDWWPRIDAVYCHSVELRSMFSETLHKAIQGCGA 456 FRLQNKNPFRIVNQPRLSWWPQTDVVHYRSAELRALFTDTLNKATOGYIA 498

\section{우}

HPAIRMAP----------SLTFKEKVTSLKFKEKPTDLETRSYKY 491 HPAIRMAP-------------SLTFKEKVTSLKFKEKPTDLETRSYKC 491 HPALRMAP--------------SLTEKEKVTSLKFKEKPTDLEARSYKY 491 HPAIRMTPMPTSHCFAWQWASVASLTFKEKMTSLKFKEKPTDLETKSYKF 506 HTPLRYITS-------------LTLKSKDTQKG---LTRAEEGPAHKM 530

LLLSMVKLIHADPKLLLCNPRKQGPETQGSTAELITGLVQLVPQSHMPEI 541 LLLSMVKLIHADPKLLLCNPRKOGPETOSSTAELITGLVOLVPOSHMPEV 541 LLLSMVKLIHADPKLLLCNPRKQGPETQGSTAELITGLVQLVPQSHMPEV 541 LLLSLVKLIHADPKLLLCNPRKQGPETQGSTAELITGLVQLVPQSSMPDI 556 LLLLLVRLIHADPTLLLNTQGKVAHEVQSSTLELINGLVSLVHQTTMPDV 580 
bioRxiv preprint doi: https://doi.org/10.1101/2021.02.18.431788; this version posted February 18, 2021. The copyright holder for this preprint (which was not certified by peer review) is the author/funder, who has granted bioRxiv a license to display the preprint in perpetuity. It is made available under aCC-BY 4.0 International license.

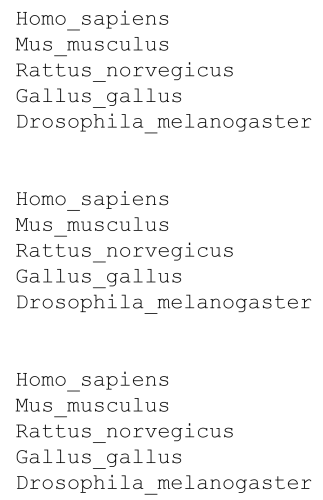

AQEAMEALLVLHOLDSIDLWNPDAPVETEWEISSOMLFYICKKLTSHOML 591 AQEAMEALLVLHQLDSIDLWNPDAPVETFWEISSQMLFYICKKLTSHQML 591 AQEAMEALLVLHQLDS IDLWNPDAPVETFWE ISSQMLFY ICKKLTSHQML 591 AQEAMEALLVLHQLDSIDLWNPDAPIETFWEISSQMLFYICKKLTSHQML 606 AQEAMEALLALHAPEKIEVWNPEAPINTFWDVSSQVLFSISQKLIQHQIA 630

SSTEILKWLREILICRNKFLLKNKQADRSSCHFLLFYGVGCDIPSSGNTS 641 SSTEILKWLREILICRNKFLLKNKQADRSSCHSLYLYGVGCEMSATGNTT 641 SSTEILKWLREI I ICRNKFLLKNKQADRSSCHSLYLYGVGCDLPASGNVT 641 SSTEILKWLREILICRNKFLLKNKOSDRTSCHFLFLYDVS------GGGAS 651 NYTDVLKWLREI LICRNTFLQRHKDYA------------------ 657

9 9

QMSMDHEELLR--TPGASLRKGKGNSSMDSAAGCSGTPPICRQAQTKLEV 689 QMSVDHDEFLRACTPGASLRKGRGNSSMDSTAGCSGTPPICROAOTKLEV 691 QMSVDHEESLRTCAPGASLRKGRGNSSMDSTAGCSGTPPICRQAQTKLEV 691 QMSLDHEEMM-RCAPGATLRKGKGNSSMESTAGCSGT-PICRQAQTKLEV 699

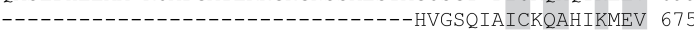

TYMELTNPDTEAVIVAMSCERHUCEEADTRCGVDEVSVHNLIPNYNTEM 739 ALYMFLWNPDTEAVLVAMSCFRHLCEEADIRCGVDEVSVHNFLPNYNTFM 741 ALYMFLWSPDTEVVLVAMSCERHLCEEADIRCGVDEVSVHNFLPNYNTFM 741 ALYMFLWSPDIEAVLVAMSCERHLCEEADIRCGVDEVSVHNFLPNYNTFM 749 VFFMYLWSVDLDAVLTSLSCEGLLCEEAEICCSSDELTVGFIMPNYHIYQ 725

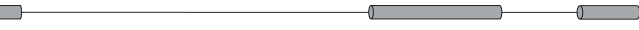

EFASVSNMMS------------TGRAALQKRVMALLRRIEHPTAGNTE 775 EFASVSNMMS------------TGRAALQKRVMALLRRIEHPTAGNIE 777 EFASVSNMLS------_-----TGRAALQKRVMALLRRIEHPTAGNTE 777 EFASVSNMMS--_-_-_-_-_--TGRAALOKRVMALLRRIEHPTAGNTE 785 ELAQLSTSATDSRICFFDNTHGNVLSRLTLQKRIMTLLRKIEHCVHGVQP 775 ㅇ

AWEDTHAKWEQATKLI LNYPKAKMEDGQAAESLHKTIVKRRMSHVSGGGS 825 AWEDTHAKWEQATKLI LNYPKAKMEDGQAAESLHKTIVKRRMSHVSGGGS 827 AWEDTHAKWEQATKLI LNYPKAKMEDGQAAESLHKT IVKRRMSHVSGGGS 827 AWEDTHAKWEQATKLILNYPKTKMEDGQVTESLHKTIVKRRMSHVSGGGS 835 AWEETFRNWEVSSKVLQTYPKCKGEDGQA-EVFHRGMGKRRASHQSSEH- 823

@

IDLSDTDSLOEWTNMTGFLCALGGVCLQORSNSGLATYSP------PMGPV 870 IDLSDTDSLQEWINMTGFLCALGGVCLQQRSSSGLATYSP------PMGAV 872 IDLSDTDSLQEWINMTGFLCALGGVCLQQRSSSGLATYSP------PMGPV 872 IDLSDTDSLQEWINMTGFLCALGGVCLQHRSNAGLATYSP-----PMGPV 880 ---DLEEQINEWANMTWELLALGGVCLHKRSSSRQMLLQQSQNNASLGSL 870

\section{ㅇ} i 9

S--------ERKGSM--------ISVMSSEGNADTPVSKFMDRLLSL 901 S---------ERKGSM--------ISVMSSEGNIDSPVSRFMDRLISL 903 S---------ERKGSM--------ISVMSSEGNVDSPVSRFMDRLISL 903 N----------ERKGSM---------ISMVSTEGNAETPVSKFIDRLLTL 911 AQNSLYSSSTSSGHGSLHPSTVSLSTLPPAPPQDVSYCPVTQFVGQLLRL 920 r i 9

MVCNHEKVGLQIRTNVKDLVGLELSPALYPMLFNKLKNTISKFFDSQGQV 951 MVCNHEKVGLQIRTNVKDLVGLELSPALYPMLFNKLKNTISKFFDSQGQV 953 MVCNHEKVGLQIRTNVKDLVGLELSPALYPMLFNKLKSAISKFFDSQGQV 953 MVCNHEKVGLQIRTNIKDLVGLELSPALYPMLFNKLKNTISKFFDSQGQV 961 LVCSNEKIGLNIQKNVKELVGEEMSTQLYPILFDQVRAIVEKFFDQQGQV 970

LI--TDTNTOFVEOTIAIMKNLTDNH---_--- TEGSSEHLGQASIETM 991 LL--SDSNTQFVEQTIAIMKNLLDNH--------TEGSSEHLGQASIETM 993 LL--TDSNTQFVEQTIAIMKNLLDNH-------TEGSSEHLGQASIETM 993 LL--TETNTQFVEQTIAIMKNLLDNH--------TEGSSEHLGQASIETM 1001 NVNVTDINTQE IEHTIYIMKS I LDPKANKDPNNDQPSPSEHLGVTSIEGM 1020

MLNLVRYVRVLGNMVHAIQIKTKLCQLVEVMMARRDDLSFCQEMKFRNKM 1041 MLNLVRYVRVLGNMVHAIQI KTKLCQLVEVMMARRDDLSFCQEMKFRNKM 1043 MLNLVRYVRVLGNMVHAIOIKTKLCOLVEVMMARRDDLSFCOEMKERNKM 1043 MLNLVRYVRVLGNLVHAIOIKTKLCOLVEVMMERRDDLSFCOEMKFRNKM 1051 MLGIVRYVRHLDMTVYAIRIKTKLCQLVEVMMKRRDDLAFRQEMKFRNKL 1070

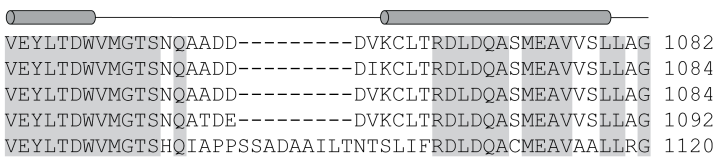


bioRxiv preprint doi: https://doi.org/10.1101/2021.02.18.431788; this version posted February 18, 2021. The copyright holder for this preprint (which was not certified by peer review) is the author/funder, who has granted bioRxiv a license to display the preprint in perpetuity. It is made available under aCC-BY 4.0 International license.

Homo sapiens Mus musculus Ratês_norvegicus Gallus_gallus Drosophila_melanogaster

Homo_sapiens Mus_musculus Ratēus norvegicus Gallus gallus Drosophila_melanogaster

Homo_sapiens Mus musculus Rattus_norvegicus Gallus gallus Drosophila_melanogaster

Homo_sapiens Mus musculus Rattus norvegicus Gallus gallus Drosophila_melanogaster

Homo sapiens Mus_musculus Ratēus_norvegicus Gallus_gallus Drosophila melanogaster

Homo_sapiens Mus_musculus Ratēus_norvegicus Gallus gallus Drosophila_melanogaster

Homo_sapiens Mus_musculus Rattus_norvegicus Gallus gallus Drosophila_melanogaster

Homo_sapiens

Mus musculus

Rattus norvegicus

Gallus gallus

Drosophila_melanogaster

Homo sapiens

Mus musculus

Ratēus_norvegicus

Gallus_gallus

Drosophila melanogaster

Homo sapiens

Mus musculus

Rattus_norvegicus

Gallus gallus

Drosophila_melanogaster

Homo_sapiens

Mus_musculus

Rattus norvegicus

Gallus gallus

Drosophila_melanogaster

Homo_sapiens

Mus musculus

Ratēus norvegicus

Gallus gallus

Drosophila_melanogaster
LPLOPEEGDGVELMEAKSOLFLKYFTLFMNLLNDCSEVEDESAOT----- 1127 LPLQPEEGDGVELMEAKSQLFLKYFTLFMNLLNDCSEVEDENAQT----- 1129 LPLQPEEGDGVELMEAKSQLFLKYFTLFMNLLNDCSEVEDENAQT----- 1129 LPLQPEEGDGVELMEAKSQLFLKYFTLFMNLLNDCSEVEDESAQT----- 1137 LPLQPEESDRGDLMDAKSALFLKYFTLFMNLLNDCIDSSEAEKEMNNTPL 1170

-GGRKRGMSRRLASLRHCTVLAMSNLLNANVDSGLMHSIGLGYHKDLQTR 1176 -GGRKRGMSRRLASLRHCTVLAMSNLLNANVDSGLMHS IGLGYHKDLQTR 1178 -GGRKRGMSRRLASLRHCTVLAMSNLLNANVDSGLMHS IGLGYHKDLQTR 1178 -GGRKRGMSRRLASLRHCTVLAMSNLLNANVDSGLMHSIGLGYHKDLQTR 1186 LPPRPRMAAGKLTALRNATI LAMSNLLGANIDSGLMHSIDLGYNPDLQTR 1220 Exit interface

ATEMEVLTKILQQGTEFDTLAETVLADRFERLVELVTMMGDQGELPIAMA 1226 ATFMEVLTKILQQGTEFDTLAETVLADRFERLVELVTMMGDQGELPIAMA 1228 ATEMEVLTKILQQGTEFDTLAETVLADRFERLVELVTMMGDQGELPIAMA 1228 ATEMEVLTKILQQGTEFDTLAETVLADRFERLVELVTMMGDQGELPIAMA 1236 AAFMEVLTOILQQGTEFDTLAETVLADRFEQLVQLVTMISDKGELPIAMA 1270 Exit interface

LANVVPCSOWDELARVLVTLFDSRHLLYOLLWNMFSKEVELADSMOTLFR 1276 LANVVPCSOWDELARVLVTLFDSRHLLYQLLWNMFSKEVELADSMQTLFR 1278 LANVVPCSOWDELARVLVTLFDSRHLLYOLLWNMFSKEVELADSMOTLFR 1278 LANVVPCSOWDELARVLVTLFDSRHLLYQLLWNMFSKEVELADSMQTLFR 1286 LANVVTTSQMDELARVLVTLFDAKHLLSPLLWNMFYREVEVSDCMQTLFR 1320

GNSLASKIMTFCFKVYGATYLOKLLDPLLRIVITSSDWOHVSFEVDPTRL 1326 GNSLASKIMTFCFKVYGATYLQKLLDPLLRVIITSSDWQHVSFEVDPTRL 1328 GNSLASKIMTFCFKVYGATYLQKLLDPLLRVIITSSDWQHVSFEVDPTRL 1328
GNSLASKIMTFCFKVYGATYLQKLLDPLLRIIITSSDWQHVSFEVDPTRL 1328 GNSLASKIMTFCFKVYGATYLQKLLEPLLRTVITSSEWQHVSFEVDPTRL 1336 GNSLGSKIMAFCFKIYGASYLQMLLEPLIRPLLDEE--EETCFEVDPARL 1368

EPSESLEENQRNLLQMTEKFFHAIISSSSEFPPQLRSVCHCLYQ------ 1370 EPSESLEENQRNLLQMTEKFFHAI ISSSSEFPSQLRSVCHCLYQ------ 1372 EPSESLEENQRNLLQMTEKFFHAI ISSSSEFPSQLRSVCHCLYQ------ 1372 EPTESLEENQRSLLQMTEKFFHAI INSSSEFPPQLRSVCHCLYQATCHSL 1386 DPTEDIEQHRNNLIALTQKVEDAI INSSDRLPPQLRSMCHCLYQVLSKRF 1418

$\longrightarrow$ PVSQRFPQNS IGAVGSAMFLRFINPAIVSPYEAGI 1405 ----------VVSQRFPQNS I GAVGSAMFLREINPAIVSPYEAGI 1407 -------------VVSQRFPQNSIGAVGSAMFLRFINPAIVSPYEAGI 1407 LNKATVKEKKENKKSVVSORFPONS IGAVGSAMFLRFINPAIVSPYEAGI 1436

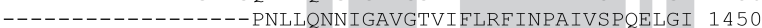

LDKKPPPRIERGLKLMSKILQSIANHVLFTKEEHMRPFNDFVKSNEDAAR 1455 LDKKPPPRIERGLKLMSKVLQSIANHVLFTKEEHMRPFNDFVKSNFDLAR 1457 LDKKPPPRIERGLKLMSKVLOS IANHVLETKEEHMRPFNDFVKSNFDLAR 1457 LDKKPPPRIERGLKLMSKILQSIANHVLFTKEEHMRPFNDFVKSNFDAAR 1486 VDKQVHSSAKRGLMLMSKILQNIANHVEFSKEQHMLCFNDFLRDHEEAGR 1500

$$
\text { 웅 }
$$

REFLDIASDCPTSDAVNHSLSFISDGNVLALHRLLWNNQEKIGQYLSSNR 1505 REFLDIASDCPTSDAVNHSLSFISDGNVLALHRLIWNNOEKIGOYLSSNR 1507 $\begin{array}{lll}\text { RFELDIASDCPTSDAVNHSLSF ISDGNVLALHRLLWNNQEKIGQYLSSNR } & 1507 \\ \text { RFFLDIASDCPTSDAVNHSLSFISDGNVLALHRLLWNNQEKIGQYLSSNR } 1507\end{array}$ RFFLDIASDCPASDTVNHSLSFISDGNVLALHRLLWNNQEKIGQYLSSNR 1536 RFFIQIASDCETVDQTSHSMSFISDANVLALHRLLWTHQEKIGDYLSSSR 1550

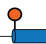

DHKAVGRRPFDKMATLLAYLGPPEHKPVAD-------THWSSLNLTSSKF 1548 $\begin{array}{lll}\text { DHKAVGRRPFDKMATLLAYLGPPEHKPVAD-------THWSSLNLTSSKF } & 1548 \\ \text { DHKAVGRRPFDKMATLLAYLGPPEHKPVAD-------THWSSLNLTSSKF } & 1550\end{array}$ DHKAVGRRPFDKMATLLAYLGPPEHKPVAD-------THWSSLNLTSSKF 1550 DHKAVGRRPFDKMATLLAYLGPPEHKPVAD-------THWSSLNLTSSKF 1579 DHKAVGRRPEDKMATLLAYLGPPEHKPVDSHMMFSSYARWSSIDMSSTNE 1600

EEFMTRHQVHEKEEFKALKTLSIFYQAGTSKAGNPIFYYVARRFKTGQIN 1598 EEFMTRHQVHEKEEFKALKTLS IFYQAGTSKAGNPIFYYVARRFKTGQIN 1600 EEFMTRHQVHEKEEFKALKTLSIFYQAGTSKAGNPIFYYVARRFKTGQIN 1600 EEFMTRHOVHEKEEFKALKTLNI FYOAGTSKAGNPVFYYIARRFKTGOIN 1629 EEIMVKHQMHEKEEFKTLKSMNIFYQAGTSKSGYPVFYYIARRYKIGETN 1650

GDLLIYHVLLTLKPYYAKPYEIVVDLTHTGPSNRFKTDFLSKWFVVFPGF 1648 GDLLIYHVLLTLKPYYAKPYEIVVDLTHTGPSNRFKTDFLSKWFVVFPGF 1650 GDLLIYHVLLTLKPYYAKPYE IVVDLTHTGPSNRFKTDFLSKWFVVFPGF 1650 GDLLIYHVLLTLKPYYAKPYEIVVDLTHAGPSNRFKTDFLSKWFVVFPGF 1679 GDLLIYHVILTLKPFCHSPFEVVIDFTHTCSDNRFRTEFLQKWFYVLPTV 1700 
bioRxiv preprint doi: https://doi.org/10.1101/2021.02.18.431788; this version posted February 18,2021 . The copyright holder for this preprint (which was not certified by peer review) is the author/funder, who has granted bioRxiv a license to display the preprint in perpetuity. It is made available under aCC-BY 4.0 International license.

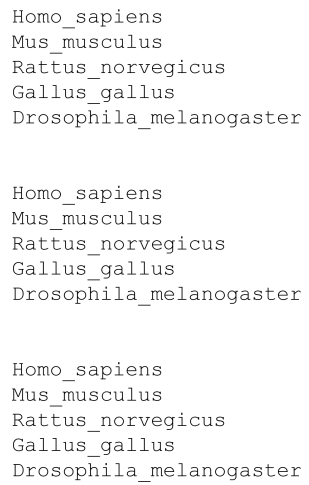

AYDNVSAVYIYNCNSWVREYTKYHERLLTGLKGSKRLVEIDCPGKLAEHI 1698 AYDNVSAVYIYNCNSWVREYTKYHERLLTGLKGSKRLIFIDCPGKLAEHI 1700 $\begin{array}{lll}\text { AYDNVSAVY IYNCNSWVREYTKYHERLLTGLKGSKRLIFIDCPGKLAEHI } & 1700 \\ \text { AYDNVSAVYIYNCNSWVREYTKYHERLLTGLKGSKRLIFIDCPGKLAEHI } & 1700\end{array}$ AYENVSAVFI YNCNSWVREYTKYHERLLTGLKGSKRLIFIDSPGKLAEHI 1729 AYENVHAVY IYNCNSWVREYTKFHDRILAPLKGNRKLLELESPNKLTDFI 1750

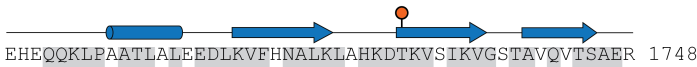

NALKLAHKDTKVSIKVGSTAVQVTSAER 174 EHEQQKLPAATLALEEDLKVFHNALKLAHKDTKVSIKVGSTAVQVTSAER 1750 EHEQQKLPAATLALEEDLKVFHNALKLAHKDTKVSIKVGSTAVQVTSAER 1750 EHDQQKLPAATLALEEDLKVFHNALKLAHKDTKVSIKVGSTAVQVTSAER 1779 DAEQQKLPGATLSLDEDLKVFSNALKLSHKDTKVAIKVGPTALQITSAEK 1800

$\mathrm{TKVLGQSVFLNDIYYASEIEEICLVDENQFTLTIANQGTPLTFMHQECEA}_{1798}$ TKVLGQSVFLNDIYYASEIEE ICLVDENQFTLTIANQGTPLTFMHQECEA 1800 TKVLGQSVFLNDIYYASEIEEICLVDENQFTLTIANQGTPLTFMHQECEA 1800 TRVLGQTVFLNDIYYASEIEEICLVDENQFTLTIANQGTPLTFMHQECEA 1829 TKVLAHSVLLNDVYYASEIEEVCLVDDNOFTLSITNESGQLSE IHNDCDN 1850

IVQSIIHIRTRWELSQPDSIPQHTKIRPKDVPGTLLNIALLNLGSSDPST 1848 IVQSIIHIRTRWELSQPDS IPQHTKIRPKDVPGTLINIALLNLGSSDPSL 1850 IVQS I IHIRTRWELSQPDS IPQHTKIRPKDVPGTLLNIALLNLGSSDPSI 1850 IVRS IIHIRTRWELSQPDS IPQHTKIRPKDVPGTLLNIALLNLGSSDPSL 1879 IVOAIIHIRNRWELSOPDSVTVHOKIRPKDVPGTLLNMALLNLGSCDPNL 1900

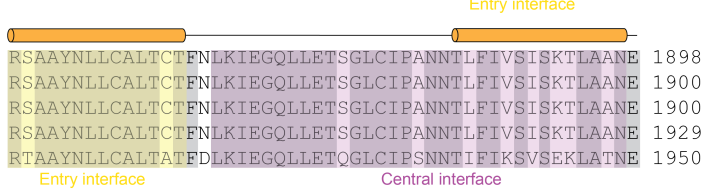

PHLTLEFLEECISGFSKSSIELKHLCLEYMTPWLSNLVRFCKHNDDAKRQ 1948 PHLTLEFLEECISGFSKSSIELKHLCLEYMTPWLSNLVRFCKHNDDAKRQ 1950 PHLTLEFLEECISGFSKSSIELKHLCLEYMTPWLSNLVRFCKHNDDAKRQ 1950 PHLTLEFLEECISGFSKSSIELKHLCLEYMTPWLSNLVRFCKHNDDAKRQ 1979 PHLTLEFLEESIQGFQRTTIELKHLCLEYMTPWLKNLVKFCKSNDDSKKL 2000
Central interface

RVTAILDKLITMTINEKQMYPSIQAKIWGSLGQITDLLDVVLDSFIKTSA 1998 RVTAILDKLITMTINEKOMYPSIOAKIWGSLGQITDLLDVVLDSFIKTSA 2000 RVIAITDKLITMTI RVTAILDKLITMINEKQMYPSIQAKIWGSLGITDLLDVULSFIKTSA 2000 RVTAILDKLITMTINEKQMYPSIQAKIWGSLGQITDLLDVVLDSFIKTSA 2029 KVSQILDKLINLTIDQKEMYPSVQAKIWGSIGQI IELIDMVLDNELHKSI 2050 Central interface

TGGLGSIKAEVMADTAVALASGNVKLVSSKVIGRMCKI IDKTCLSPTPTL 2048 TGGLGSIKAEVMADTAVALASGNVKLVSSKVIGRMCKIIDKTCLSPTPTL 2050 TGGLGSIKAEVMADTAVALASGNVKLVSSKVIGRMCKIIDKTCLSPTPTL 2050 $\begin{array}{lll}\text { TGGLGS IKAEVMADTAVALASGNVKLVSSKVIGRMCKI IDKTCLSPTPTL } & 2050 \\ \text { TGGLGSIKAEVMADTAVALASGNVKLVSSKVIGRMCKI IDKTCLSPTPTL } & 2079\end{array}$ TYGLGSPQVEIMADTAVALASANVQLVSKKVITRICRVMDKSCTNPTQYL 2100 Central interface

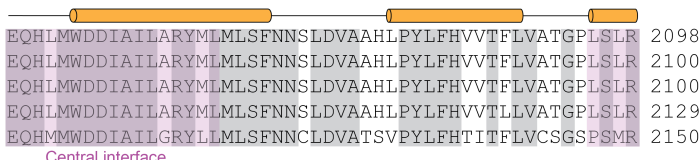
Central interface

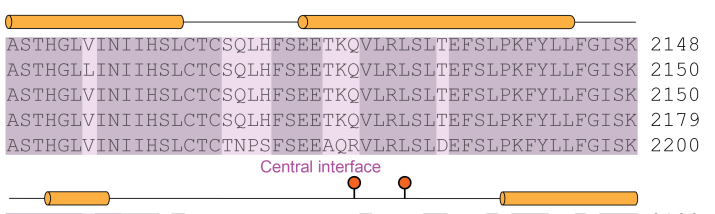

VKSAAVIAFRSSYRDR---------SFSPGSYERETFALTSLETVTEALL 2189 VKSAAVIAFRSSYRDR---------SFSPGSYERETFALTSLETVTEALI 2191 VKSAAVIAFRSSYRDR--------SFSPGSYERETFALTSLETVTEALI 2191 VKSAAVIAFRSSYRDR---------SFSPGSYERETFALTSLETVTEALI 2220 VKSAAVTAFRSSCRHPTDKWLGNERVTQPLPADRERLSLPSLEVITDALL 2250

EIMEACMRDIPTCKWLDQWTELAQRFAFQYNPSLQPRALVVFGCISKRVS 2239 EIMEACMRDIPTCKWLDQWTELAQRFAFQYNPSLQPRALVVFGCISKRVS 2241 EIMEACMRDIPTCKWLDQWTELAQRFAFQYNPSLQPRALVVFGCISKRVS 2241 EIMEACMRDIPTCKWIDOWTELAOKFAFQYNPSLQPRALVVFGCISKRVS 2270 EIMEACMRDVPDCEWLNTWTSLARSFAFCYNPALQPRALIVYGCISKSVT 2300 
bioRxiv preprint doi: https://doi.org/10.1101/2021.02.18.431788; this version posted February 18, 2021. The copyright holder for this preprint (which was not certified by peer review) is the author/funder, who has granted bioRxiv a license to display the preprint in perpetuity. It is made available under aCC-BY 4.0 International license.

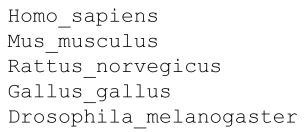

Homo_sapiens

Mus_musculus

Rattus norvegicus

Gallus gallus

Drosophila melanogaster

Homo_sapiens

Mus_musculus

Rattus norvegicus

Gallus gallus

Drosophila melanogaster

Homo_sapiens

Mus musculus

Rattus norvegicus

Gallus gallus

Drosophila_melanogaster

Homo_sapiens

Tus musc

Rattus_norvegicus

Gallus_gallus

Drosophila_melanogaster

Homo_sapiens

Mus musculus

RatEus_norvegicus

Gallus_gallus

Drosophila melanogaster

Homo sapiens

Mus musculus

RatEus_norvegicus

Gallus gallus

Drosophila melanogaster

Homo sapiens

Mus_musculus

Rattus_norvegicus

Gallus_gallus

Drosophila melanogaster

Homo_sapiens

Mus musculus

Rattus norvegicus

Gallus gallus

Drosophila melanogaster

Homo_sapiens

Mus musculus

Rattus norvegicus

Gallus gallus

Drosophila_melanogaster
HGOIKOI IRILSKALESCLKGPDTYNSOVLIEATVIALTKLOPLLNKDSP 2289 HGQIKQI IRILSKALESCLKGPDTYNSQVLIESTVIALTKLQPLINKDSP 2291 HGQIKQIIRILSKALESCLKGPDTYNSQVLIEATVIALTKLQPLLNKDSP 2291 HGQIKQI IRI LSKGLESCLKGPDNYNSQVLIEATVIALTKLQPLLNKDSP 2320 DHEVKQLLRILVKALE-------SFNDLILIEALVMCLTRIQPLLRPESP 2343

LHKALFWVAVAVLQLDEVNLYSAGTALLEQNLHTLDSLRIFNDKS-PEEV 2338 LHKALFWVAVAVLQLDEVNLYSAGTALLEQNLHTLDSLRIFNDKS-PEEV 2340 LHKALFWVAVAVLQLDEVNLYSAGTALLEQNLHTLDSLRIFNDKS-PEEV 2340 MHKALFWVAMAVLQLDEVNLYSAGTALLEQNLHTLDSLRVFNDKS-PEEV 2369 IHRALFWVAISVLQLDEITLYGAGLALLEQNLHTLKSQGCFDKKETIAEV 2393

FMAIRNPLEWHCKOMDHFVGLNENSNFNFALVGHLLKGYRHPSPAIVART 2388 FMAIRNPLEWHCKQMDHFVGLNFNSNFNFALVGHLLKGYRHPSPAIVART 2390 FMAIRNPLEWHCKQMDHFVGLNFNSNFNFALVGHLLKGYRHPSPAIVART 2390 FMEIRRPLEWHCKQMDHFVGLNENSNFNFALVGHLLKGYRHPSPTTVART 2419 MMKTREKLEWHFKQLDHAVGLSERSNEHFALVGHLIKGFRHPTPTTVSRT 2443

\section{오 우}

VRILHTLLTLVNKHRNCDKFEVNTQSVAYLAALLTVSEEVRSRCSLKHRK 2438 VRILHTLLTLVNKHRNCDKFEVNTQSVAYLAALLTVSEEVRSRCSLKHRK 2440 VRILHTLLTLVNKHRNCDKFEVNTQSVAYLAALLTVSEEVRSRCSLKHRK 2440 VRILHTLLALVNKHRNCDKFEVNTQSVAYLAALLTVSEEVRSRCSLKHRK 2469 SRVLTMLLGIIAKPLHRDKFEVTPDSVAYLTALVAVSEEVRSRCHVKHAL 2493

\section{$9 \quad 9 \quad 9 \quad 9$ 9 9 9 99}

SLLLTDISMENVPMDTYPIHHGDPSYRTLKETQPWSSPKGSEGYLAATYP 2488 SLLLTDISMENVPMDTYPIHHGDPSYRTLKETQPWSSPKGSEGYLAATYP 2490 SLLLTDISMENVPMDTYPIHHGDPSSRTLKETQPWSSPRGSEGYLAATYP 2490 SLLLTDVAMENVPMDTYPIHHSDTTYRTLKENQPWSSPKGSDRHLAASYP 2519 PRWPADLSSSVENGEAS-GGVQAIGLPLSRRQKSWDILDQSALQF----- 2537$$
\text { M }
$$$$
\text { ? }
$$

TVGQTSPRARKSMSLDMGQPSQANTKKLLGTRKSFDHLISDTKAPKRQEM 2538 AVGQTSPRARKSMSLDMGQPSOANTKKLLGTRKSFDHLISDTKAPKROEM 2540 AVGQTSPRARKSMSLDMGQPSQANTKKLLGTRKSFDHLISDTKAPKRQEM 2540 TVGQISPRTRKSMSLDMGQPSQANTKKLLGTRKSFDHLISDTKAPKRQDM 2569 -------ARQHKVPTLQNARVLFKTQRSESVPT--TKDPN---N 2569

\section{우 9 우 9 우우}

ESGITTPPKMRRVAETDYEMETQRISSSQQHPHLRKVSVSESNVLLDEEV 2588 ESGITTPPKMRRVAETDYEMETORIPSSOOHPHLRKVSVSESNVLLDEEV 2590 ESGITTPPKMRRVAETDYEMETQRISSSQQHPHLRKVSVSESNVLLDEEV 2590 ESGITTPPKMRRVAENDYEMETQRIS-PQQHPHLRKVSVSESNVLLDEEV 2618 ATGI---------------EERQERGSRSSVSNESNVLLDPEV 2597

$\longrightarrow$

LTDPKIOALLLTVLATLVKYTTDEFDQRI LYEYLAEASVVFPKVFPVVHN 2638 LTDPKIQALLLTVLATLVKYTTDEFDQRILYEYLAEASVVFPKVFPVVHN 2640 LTDPKIQALLLTVLATLVKYTTDEFDQRILYEYLAEASVVFPKVFPLVHN 2640 LTDPKIQALLLTVLATLVKYTTDEFDQRILYEYLAEASVVFPKVFPVVHN 2668 LPDLSIQALVLTVLATLVKYSSDEGETRVLYQYLAEGSVVFPKVFPVIHS 2647

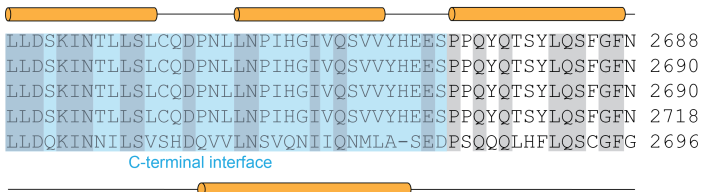

GLWRFAGPFSKQTQIPDYAELIVKFLDALIDTYLPGIDEETSEESLLTPT 2738 GLWRFAGPFSKQTQIPDYAELIVKFLDALIDTYLPGIDEETSEESLLTPT 2740 GLWRFAGPFSKQTQIPDYAELIVKFLDALIDTYLPGIDEETSEESLLTPT 2740 GLWRFAGPFSKQTQIPDYAELIVKFLDALIDTYLPGIDEETSEESLLTPT 2768 GLWRFAGPFTKYNMMGESSELFVNCLEAMVETCLPGDESAP------VPP 2740

SPYPPALQSQLSITA---NLNLSNSMTSLATSQHSP-------------- 2771 SPYPPALQSQLSITA---NLNLSNSMTSLATSQHSP------------ 2773 SPYPPALQSQLSITA---NLNLSNSMTSLATSQHSP-------------- 2773 SPYPPAVQSOLSITA---NLNLSNSMTSLATSOHSPASLPCSKSAVFMOL 2815 SPRPYNLSSSLSSLTLGSPTDKAFSSESLDFYDNCPGSVSSLRRAS---- 2786

\section{O 0 O 0 O}

---GIDKENVELSPTTGHCNSGRTRHGSASQVQKQRSAGSFKRNSIKKIV 2818 ---GLDKENVELSPTAGHCNSGRTRHGSASQVQKQRSAGSFKRNSIKKIV 2820 ---GIDKENVELSPTTGHCNSGRTRHGSASQVQKQRSAGSFKRNSIKKIV 2820 PHQGIDKENVELSPTTGHTNSGRMRHGSASQVQKQRSAGSLKRHSIKKIV 2865 HSKSRAKHRINDSPSH-------- 2802

Fig. S9. NF1 multiple sequence alignment and secondary structure assignment. Multiple sequence alignment of NF1. Conserved regions are highlighted in grey with the secondary assignment from the NF1 structure indicate above the alignments. Key sites of phosphorylation(51) and dimer interfaces are indicated. 
bioRxiv preprint doi: https://doi.org/10.1101/2021.02.18.431788; this version posted February 18, 2021. The copyright holder for this preprint (which was not certified by peer review) is the author/funder, who has granted bioRxiv a license to display the preprint in perpetuity. It is made available under aCC-BY 4.0 International license.

Table S1. Cryo-electron microscopy data collection, processing and analysis statistics.

\begin{tabular}{|c|c|c|c|}
\hline & \multicolumn{3}{|c|}{ Data collection and processing } \\
\hline & \multicolumn{3}{|c|}{ NF1 } \\
\hline Microscope & \multicolumn{3}{|c|}{ Talos Arctica } \\
\hline Voltage (keV) & \multicolumn{3}{|c|}{200} \\
\hline Camera & \multicolumn{3}{|c|}{ Falcon III } \\
\hline Mode & \multicolumn{3}{|c|}{ Counting } \\
\hline Exposure nagivation & \multicolumn{3}{|c|}{ Beam tilt } \\
\hline Set defocus range $(\mu \mathrm{m})$ & \multicolumn{3}{|c|}{-0.5 to -2.0} \\
\hline Measured defocus $(\mu \pm \sigma)(\mu \mathrm{m})$ & \multicolumn{3}{|c|}{$-1.2 \pm 0.7$} \\
\hline Exposure rate (e- / pixel / s) & \multicolumn{3}{|c|}{0.8} \\
\hline Frames & \multicolumn{3}{|c|}{50} \\
\hline Exposure duration (s) & \multicolumn{3}{|c|}{71.68} \\
\hline Total exposure (e- / $\AA 2$ ) & \multicolumn{3}{|c|}{40.22} \\
\hline Magnification & \multicolumn{3}{|c|}{$120 k$} \\
\hline Starting pixel size ( $\AA$ / pixel) & \multicolumn{3}{|c|}{1.194} \\
\hline Micrographs & \multicolumn{3}{|c|}{2,675} \\
\hline Particles (Total extracted) & 193,225 & \multicolumn{2}{|c|}{$191,128^{\wedge}$} \\
\hline Particles (Final reconstruction) & 95,564 & $34,993^{\wedge}$ & $9,238^{\wedge}$ \\
\hline Reconstruction Strategy & Standard & $\begin{array}{l}\text { Symmetry expand I } \\
\text { Localised reconstruction }\end{array}$ & $\begin{array}{l}\text { 3DPCA clustering I } \\
\text { Local refinement }\end{array}$ \\
\hline Binning factor & 2 & 1 & 1 \\
\hline Imposed symmetry & $\mathrm{C} 2$ & $\mathrm{C} 1$ & $\mathrm{C} 1$ \\
\hline \multicolumn{4}{|l|}{ Global Resolution $(\AA)$} \\
\hline 0.143 (Unmasked / Masked) & $7.6 / 5.6$ & $5.18 / 4.56$ & $8.0 / 6.3$ \\
\hline Local resolution variation\# & $5.3-19.2$ & $7.3-4.2$ & $4.58-15.8$ \\
\hline Global B-factor $\left(\AA^{2}\right)$ (manual) & -200 & -80 & -100 \\
\hline EMDB identifier* & EMBD $X X X X$ & EMBD $X X X X$ & EMBD $X 0 X X$ \\
\hline
\end{tabular}

\#As determined by windo wed FSC at 0.5 criterion in Relion (3.1) or cryoSPARC (3.1) *M ask, half-maps, unsharpened map, final map where applicable. ^ Sub/symmetry expanded particles

\begin{tabular}{|c|c|c|c|}
\hline & \multicolumn{3}{|c|}{ Model statistics } \\
\hline & NF1 homodimer core & NF1 wing & NF1 autoinhibited state \\
\hline \multicolumn{4}{|l|}{ Model-to-map } \\
\hline Correlation Coefficient (volume) & 0.71 & 0.70 & 0.62 \\
\hline Resolution Estimates ( $\AA$, FSC $0.143 / 0.5)$ & $5.6 / 7.6$ & $3.7 / 5.2$ & $4.6 / 7.4$ \\
\hline \multicolumn{4}{|l|}{$B$ factors $\left(\AA^{2}\right)$} \\
\hline Protein & 125.47 & 127.23 & 115.23 \\
\hline Ligand & N/A & $\mathrm{N} / \mathrm{A}$ & N/A \\
\hline \multicolumn{4}{|l|}{ R.M.S. deviation } \\
\hline Bonds $(\AA)$ & 0.005 & 0 & 0.005 \\
\hline Angles $\left({ }^{\circ}\right)$ & 1.067 & 0.01 & 1.08 \\
\hline All-atom clash score & 33.9 & 31.6 & 16.1 \\
\hline \multicolumn{4}{|l|}{ Ramachandran plot (\%) } \\
\hline Favoured & 94.74 & 94.76 & 95.27 \\
\hline Allowed & 5.26 & 5.24 & 4.68 \\
\hline Outliers & 0 & 0 & 0.05 \\
\hline CaBLAM outlier (\%) & 3.97 & 2.48 & 3.10 \\
\hline Rotamer outliers (\%) & 0 & 0.14 & 0.96 \\
\hline C-beta deviations (\%) & 0 & 0 & 0 \\
\hline Molprobity Score & 2.21 & 2.34 & 2.04 \\
\hline PDB identifier & PDB $X X X X$ & PDB $X X X X$ & PDB $X X X X$ \\
\hline
\end{tabular}


bioRxiv preprint doi: https://doi.org/10.1101/2021.02.18.431788; this version posted February 18, 2021. The copyright holder for this preprint (which was not certified by peer review) is the author/funder, who has granted bioRxiv a license to display the preprint in perpetuity. It is made available under aCC-BY 4.0 International license.

Table S2. NF1 crosslinking mass spectrometry sites.

See Extended_data_table_2.xlsx 
NF1 BS2G

Residue 1 Protein 1 Residue 2 Protein 2 \# XLS

\begin{tabular}{|c|c|c|}
\hline $33 \mathrm{~N}$ & $77 \mathrm{~N}$ & 12 \\
\hline $48 \mathrm{~N}$ & $99 \mathrm{~N}$ & 6 \\
\hline $48 \mathrm{~N}$ & $2468 \mathrm{C}$ & 3 \\
\hline $48 \mathrm{~N}$ & $2515 \mathrm{C}$ & 6 \\
\hline $63 N$ & $111 \mathrm{~N}$ & 9 \\
\hline $63 N$ & $2499 \mathrm{C}$ & 2 \\
\hline $77 \mathrm{~N}$ & $469 \mathrm{~N}$ & 2 \\
\hline $77 \mathrm{~N}$ & $471 \mathrm{~N}$ & 2 \\
\hline $77 \mathrm{~N}$ & $478 N$ & 3 \\
\hline $77 \mathrm{~N}$ & 2499 C & 2 \\
\hline $99 \mathrm{~N}$ & $111 \mathrm{~N}$ & 11 \\
\hline $99 \mathrm{~N}$ & $189 \mathrm{~N}$ & 21 \\
\hline $99 \mathrm{~N}$ & $2499 \mathrm{C}$ & 3 \\
\hline $99 \mathrm{~N}$ & $2515 \mathrm{C}$ & 3 \\
\hline $99 \mathrm{~N}$ & $2521 \mathrm{C}$ & 2 \\
\hline $111 \mathrm{~N}$ & $2499 \mathrm{C}$ & 6 \\
\hline $111 \mathrm{~N}$ & $2515 \mathrm{C}$ & 6 \\
\hline $111 \mathrm{~N}$ & $2521 \mathrm{C}$ & 3 \\
\hline $195 \mathrm{~N}$ & $248 \mathrm{~N}$ & 2 \\
\hline $206 \mathrm{~N}$ & $261 \mathrm{~N}$ & 366 \\
\hline $261 \mathrm{~N}$ & $305 \mathrm{~N}$ & 9 \\
\hline $263 N$ & $305 \mathrm{~N}$ & 19 \\
\hline $449 \mathrm{~N}$ & $469 \mathrm{~N}$ & 4 \\
\hline $449 \mathrm{~N}$ & $471 \mathrm{~N}$ & 6 \\
\hline $449 \mathrm{~N}$ & $478 \mathrm{~N}$ & 4 \\
\hline $449 \mathrm{~N}$ & $480 \mathrm{~N}$ & 3 \\
\hline $449 \mathrm{~N}$ & $490 \mathrm{~N}$ & 2 \\
\hline $469 \mathrm{~N}$ & $480 \mathrm{~N}$ & 9 \\
\hline $469 \mathrm{~N}$ & $490 \mathrm{~N}$ & 11 \\
\hline $469 \mathrm{~N}$ & $584 \mathrm{~N}$ & 2 \\
\hline $469 \mathrm{~N}$ & $662 \mathrm{~N}$ & 2 \\
\hline $469 \mathrm{~N}$ & $789 \mathrm{~N}$ & 2 \\
\hline $471 \mathrm{~N}$ & $490 \mathrm{~N}$ & 13 \\
\hline $471 \mathrm{~N}$ & $584 \mathrm{~N}$ & 3 \\
\hline $476 \mathrm{~N}$ & $490 \mathrm{~N}$ & 4 \\
\hline $478 \mathrm{~N}$ & $490 \mathrm{~N}$ & 20 \\
\hline $490 \mathrm{~N}$ & $810 \mathrm{~N}$ & 2 \\
\hline $505 \mathrm{~N}$ & 2515 C & 5 \\
\hline $609 \mathrm{~N}$ & $2468 \mathrm{C}$ & 7 \\
\hline $609 \mathrm{~N}$ & 2499 C & 4 \\
\hline $609 \mathrm{~N}$ & $2514 \mathrm{C}$ & 2 \\
\hline
\end{tabular}




\begin{tabular}{|c|c|c|}
\hline $609 \mathrm{~N}$ & $2515 \mathrm{C}$ & 4 \\
\hline $609 \mathrm{~N}$ & $2531 \mathrm{C}$ & 3 \\
\hline $609 \mathrm{~N}$ & $2547 \mathrm{C}$ & 2 \\
\hline $613 \mathrm{~N}$ & $2468 \mathrm{C}$ & 3 \\
\hline $613 \mathrm{~N}$ & $2515 \mathrm{C}$ & 2 \\
\hline $613 \mathrm{~N}$ & $2521 \mathrm{C}$ & 2 \\
\hline $615 \mathrm{~N}$ & $662 \mathrm{~N}$ & 3 \\
\hline $615 \mathrm{~N}$ & 1436 GRD & 5 \\
\hline $615 \mathrm{~N}$ & $2468 C$ & 4 \\
\hline $615 \mathrm{~N}$ & $2499 \mathrm{C}$ & 4 \\
\hline $615 \mathrm{~N}$ & $2514 \mathrm{C}$ & 3 \\
\hline $615 \mathrm{~N}$ & $2515 \mathrm{C}$ & 2 \\
\hline $662 \mathrm{~N}$ & $874 N$ & 4 \\
\hline $662 \mathrm{~N}$ & 1419 GRD & 4 \\
\hline $757 \mathrm{~N}$ & $2468 \mathrm{C}$ & 2 \\
\hline $757 \mathrm{~N}$ & $2514 \mathrm{C}$ & 2 \\
\hline $757 N$ & $2521 \mathrm{C}$ & 2 \\
\hline $789 \mathrm{~N}$ & $810 \mathrm{~N}$ & 19 \\
\hline $789 \mathrm{~N}$ & $874 \mathrm{~N}$ & 7 \\
\hline $789 \mathrm{~N}$ & $893 \mathrm{~N}$ & 43 \\
\hline $796 \mathrm{~N}$ & $810 \mathrm{~N}$ & 14 \\
\hline $796 \mathrm{~N}$ & $874 N$ & 3 \\
\hline $796 \mathrm{~N}$ & $908 \mathrm{~N}$ & 9 \\
\hline $798 \mathrm{~N}$ & $908 \mathrm{~N}$ & 12 \\
\hline $810 \mathrm{~N}$ & $908 \mathrm{~N}$ & 2 \\
\hline $874 \mathrm{~N}$ & $938 \mathrm{~N}$ & 32 \\
\hline $874 \mathrm{~N}$ & $943 \mathrm{~N}$ & 10 \\
\hline $874 \mathrm{~N}$ & $1036 \mathrm{~N}$ & 6 \\
\hline $874 \mathrm{~N}$ & 1408 GRD & 12 \\
\hline $874 \mathrm{~N}$ & 1419 GRD & 10 \\
\hline $874 \mathrm{~N}$ & 1423 GRD & 6 \\
\hline $874 \mathrm{~N}$ & 1560 SECPH & 9 \\
\hline $874 \mathrm{~N}$ & $1567 \mathrm{SECPH}$ & 5 \\
\hline $918 \mathrm{~N}$ & $938 \mathrm{~N}$ & 2 \\
\hline $918 \mathrm{~N}$ & $1014 \mathrm{~N}$ & 7 \\
\hline $938 \mathrm{~N}$ & $1036 \mathrm{~N}$ & 2 \\
\hline $1036 \mathrm{~N}$ & $1062 \mathrm{~N}$ & 2 \\
\hline $1036 \mathrm{~N}$ & $1560 \mathrm{SECPH}$ & 39 \\
\hline $1036 \mathrm{~N}$ & 1704 SECPH & 7 \\
\hline $1040 \mathrm{~N}$ & $1062 \mathrm{~N}$ & 4 \\
\hline 1345 GRD & $2521 \mathrm{C}$ & 3 \\
\hline 1419 GRD & $2468 \mathrm{C}$ & 3 \\
\hline 1448 GRD & $2515 \mathrm{C}$ & 3 \\
\hline
\end{tabular}




\begin{tabular}{|c|c|}
\hline 1496 GRD & 1508 GRD \\
\hline 1496 GRD & 1567 SECPH \\
\hline 1496 GRD & 1704 SECPH \\
\hline 1496 GRD & $2468 C$ \\
\hline 1496 GRD & 2499 C \\
\hline 1496 GRD & $2515 \mathrm{C}$ \\
\hline 1496 GRD & $2802 \mathrm{C}$ \\
\hline 1508 GRD & $2139 \mathrm{C}$ \\
\hline 1508 GRD & $2286 \mathrm{C}$ \\
\hline 1508 GRD & $2401 \mathrm{C}$ \\
\hline 1508 GRD & $2407 \mathrm{C}$ \\
\hline 1508 GRD & $2468 C$ \\
\hline 1508 GRD & $2499 C$ \\
\hline 1508 GRD & $2514 \mathrm{C}$ \\
\hline 1508 GRD & $2515 \mathrm{C}$ \\
\hline 1508 GRD & $2521 \mathrm{C}$ \\
\hline 1508 GRD & $2531 \mathrm{C}$ \\
\hline 1531 GRD & 1634 SECPH \\
\hline 1567 SECPH & 1704 SECPH \\
\hline 1634 SECPH & $1823 \mathrm{C}$ \\
\hline 1634 SECPH & $1827 \mathrm{C}$ \\
\hline 1634 SECPH & 1946 C \\
\hline 1634 SECPH & $2515 \mathrm{C}$ \\
\hline 1634 SECPH & $2802 \mathrm{C}$ \\
\hline 1634 SECPH & $2810 \mathrm{C}$ \\
\hline 1670 SECPH & 1728 SECPH \\
\hline 1670 SECPH & $2802 \mathrm{C}$ \\
\hline 1670 SECPH & $2810 \mathrm{C}$ \\
\hline $1680 \mathrm{SECPH}$ & $2802 \mathrm{C}$ \\
\hline 1693 SECPH & 1735 SECPH \\
\hline 1728 SECPH & $2810 \mathrm{C}$ \\
\hline 1731 SECPH & $2802 \mathrm{C}$ \\
\hline 1731 SECPH & $2810 \mathrm{C}$ \\
\hline $1823 \mathrm{C}$ & 1946 C \\
\hline $1827 \mathrm{C}$ & 1946 C \\
\hline 1915 C & 1956 C \\
\hline $1940 \mathrm{C}$ & 2028 C \\
\hline $1940 \mathrm{C}$ & $2810 \mathrm{C}$ \\
\hline 1946 C & $2802 \mathrm{C}$ \\
\hline 1946 C & $2810 \mathrm{C}$ \\
\hline 1956 C & $2006 C$ \\
\hline 1956 C & $2802 \mathrm{C}$ \\
\hline 1956 C & $2810 \mathrm{C}$ \\
\hline
\end{tabular}




\begin{tabular}{|c|c|}
\hline $1965 \mathrm{C}$ & 2006 C \\
\hline 1965 C & $2802 \mathrm{C}$ \\
\hline $1965 \mathrm{C}$ & $2810 \mathrm{C}$ \\
\hline $2006 \mathrm{C}$ & $2802 \mathrm{C}$ \\
\hline 2023 C & $2203 \mathrm{C}$ \\
\hline 2023 C & $2802 \mathrm{C}$ \\
\hline $2028 \mathrm{C}$ & $2810 \mathrm{C}$ \\
\hline 2035 C & $2810 \mathrm{C}$ \\
\hline $2148 \mathrm{C}$ & $2468 \mathrm{C}$ \\
\hline $2148 \mathrm{C}$ & 2499 C \\
\hline $2150 \mathrm{C}$ & $2468 \mathrm{C}$ \\
\hline $2150 \mathrm{C}$ & 2499 C \\
\hline $2150 \mathrm{C}$ & $2515 \mathrm{C}$ \\
\hline $2203 C$ & $2802 \mathrm{C}$ \\
\hline 2203 C & $2810 \mathrm{C}$ \\
\hline $2244 \mathrm{C}$ & $2802 \mathrm{C}$ \\
\hline $2252 \mathrm{C}$ & $2802 \mathrm{C}$ \\
\hline $2252 \mathrm{C}$ & $2810 \mathrm{C}$ \\
\hline $2435 \mathrm{C}$ & $2515 \mathrm{C}$ \\
\hline $2438 C$ & $2468 \mathrm{C}$ \\
\hline $2438 \mathrm{C}$ & 2499 C \\
\hline $2438 C$ & $2515 \mathrm{C}$ \\
\hline $2468 C$ & $2499 \mathrm{C}$ \\
\hline $2468 C$ & $2514 \mathrm{C}$ \\
\hline $2468 C$ & $2515 \mathrm{C}$ \\
\hline $2468 C$ & $2521 \mathrm{C}$ \\
\hline $2468 \mathrm{C}$ & $2531 \mathrm{C}$ \\
\hline $2468 C$ & $2547 \mathrm{C}$ \\
\hline $2468 \mathrm{C}$ & $2574 \mathrm{C}$ \\
\hline $2468 C$ & $2699 \mathrm{C}$ \\
\hline $2477 \mathrm{C}$ & 2499 C \\
\hline $2477 \mathrm{C}$ & $2515 \mathrm{C}$ \\
\hline 2499 C & $2515 \mathrm{C}$ \\
\hline 2499 C & $2521 \mathrm{C}$ \\
\hline $2499 C$ & $2531 \mathrm{C}$ \\
\hline 2499 C & $2547 \mathrm{C}$ \\
\hline $2499 \mathrm{C}$ & $2699 \mathrm{C}$ \\
\hline $2514 \mathrm{C}$ & $2531 \mathrm{C}$ \\
\hline $2514 \mathrm{C}$ & $2547 \mathrm{C}$ \\
\hline $2514 \mathrm{C}$ & 2699 C \\
\hline $2515 \mathrm{C}$ & $2531 \mathrm{C}$ \\
\hline $2515 \mathrm{C}$ & $2547 \mathrm{C}$ \\
\hline 2515 C & $2699 \mathrm{C}$ \\
\hline
\end{tabular}


bioRxiv preprint doi: https://doi.org/10.1101/2021.02.18.431788; this version posted February 18, 2021. The copyright holder for this preprint (which was not certified by peer review) is the author/funder, who has granted bioRxiv a license to display the preprint in perpetuity. It is made available under aCC-BY 4.0 International license.

2515 C

$2521 \mathrm{C}$

$2531 \mathrm{C}$

2699 C
$2810 \mathrm{C}$

2547 C

$2547 \mathrm{C}$

$2802 \mathrm{C}$
1

12

9 